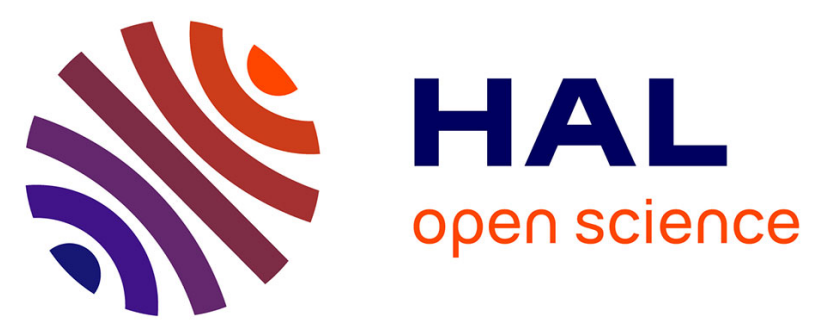

\title{
Sacral Anterior Root Stimulation (SARS) and Visceral Function Outcomes in Spinal Cord Injury-A Systematic Review of the Literature Over Four Decades
} Thomas Guiho, Christine Azevedo Coste, Luc Bauchet, Claire Delleci, Jean-Rodolphe Vignes, David Guiraud, Charles Fattal

\section{To cite this version:}

Thomas Guiho, Christine Azevedo Coste, Luc Bauchet, Claire Delleci, Jean-Rodolphe Vignes, et al.. Sacral Anterior Root Stimulation (SARS) and Visceral Function Outcomes in Spinal Cord Injury-A Systematic Review of the Literature Over Four Decades. World Neurosurgery, 2021, 10.1016/j.wneu.2021.09.041 . hal-03375512

\section{HAL Id: hal-03375512 \\ https://hal.inria.fr/hal-03375512}

Submitted on 13 Oct 2021

HAL is a multi-disciplinary open access archive for the deposit and dissemination of scientific research documents, whether they are published or not. The documents may come from teaching and research institutions in France or abroad, or from public or private research centers.
L'archive ouverte pluridisciplinaire HAL, est destinée au dépôt et à la diffusion de documents scientifiques de niveau recherche, publiés ou non, émanant des établissements d'enseignement et de recherche français ou étrangers, des laboratoires publics ou privés. 


\section{Title page}

\section{1) Publication Title}

Sacral Anterior Root Stimulation (SARS) and visceral function outcomes in spinal cord injury - a systematic review of literature over four decades

\section{2) Running Title}

Forty years of sacral anterior roots stimulation

\section{3) Authors}

Thomas Guiho $\mathrm{PhD}^{1,2^{*}}$; Christine Azevedo-Coste $\mathrm{PhD}^{1}$; Luc Bauchet $\mathrm{MD}, \mathrm{PhD}^{3}$; Claire Delleci MD ${ }^{4}$; Jean-Rodolphe Vignes $\mathrm{MD}, \mathrm{PhD}^{5}$; David Guiraud $\mathrm{PhD}^{1}$; Charles Fattal MD, $\mathrm{PhD}^{6}$.

\section{4) Affiliations}

${ }^{1}$ INRIA, Centre Sophia Antipolis, CAMIN team, Montpellier, Occitanie, France

${ }^{2}$ Biosciences Institute, Newcastle University, Newcastle upon Tyne, Tyne and Wear, UK

${ }^{3}$ Department of neurosurgery, Gui de Chauliac Hospital, CHU Montpellier, Montpellier University Medical Center, Montpellier, Occitanie, France

${ }^{4}$ Department of physical medicine and rehabilitation, Pellegrin Hospital, CHU Bordeaux, Bordeaux University Medical Center, Bordeaux, Nouvelle Aquitaine, France 
${ }^{5}$ Department of neurosurgery, Pellegrin Hospital, CHU Bordeaux, Bordeaux University

Medical Center, Bordeaux, Nouvelle Aquitaine, France

${ }^{6}$ Centre Bouffard-Vercelli, Pôle Santé Roussillon, 66000 Perpignan, France

\section{5) Corresponding author}

Thomas Guiho

Email

thomas.guiho@inria.fr / thomas.guiho@ncl.ac.uk

$\underline{\text { Adress }}$

Thomas Guiho

INRIA - Campus Saint Priest, Bat. 5

860 Rue de St Priest

34095 Montpellier cedex 5 - France

\section{6) Keywords}

Literature review, Neuroprosthesis, Spinal Cord Injury, Visceral fonctions, Sacral Anterior Root Stimulation.

Accepted for publication in World Neurosurgery the $8^{\text {th }}$ of September 2021 
Sacral Anterior Root Stimulation (SARS) and visceral function outcomes in spinal cord injury - a systematic review of literature over four decades

Thomas Guiho $\mathrm{PhD}^{1,2^{*}}$; Christine Azevedo-Coste $\mathrm{PhD}^{1}$; Luc Bauchet $\mathrm{MD}, \mathrm{PhD}^{3}$; Claire Delleci $\mathrm{MD}^{4}$; Jean-Rodolphe Vignes MD, $\mathrm{PhD}^{5}$; David Guiraud $\mathrm{PhD}^{1}$; Charles Fattal MD, $\mathrm{PhD}^{6}$

\section{$\underline{\text { Abstract }}$}

\section{Study design: Systematic Review}

Objectives: The sacral anterior root stimulator (SARS) was developed 40 years ago to restore urinary and bowel functions to individuals with spinal cord injury (SCI). Mostly used to restore lower urinary tract function, SARS implantation is coupled with sacral deafferentation to counteract the problems of chronic detrusor sphincter dyssynergia and detrusor overactivity. In this article, we systematically review 40 years of SARS implantation and assess the medical added-value of this approach in accordance with the PRISMA guidelines (Preferred Reporting Items for Systematic reviews and Meta-Analyses). We identified four axes of investigation: i) impact on visceral functions, ii) implantation safety and device reliability, iii) individuals quality of life, and iv) additional information about the procedure.

Methods: Three databases were consulted: Pubmed, EBSCOhost and Pascal. 219 abstracts were screened and 38 publications were retained for analysis (1,147 implantations).

Results: The SARS technique showed good clinical results (85.9\% of individuals used their implant for micturition and $67.9 \%$ to ease bowel movements) and improved individual quality 
of life. Conversely, several sources of complications were reported after implantation (surgical complications, failures etc.).

Conclusions: Despite promising results, a decline in implantations was observed. This decline can be linked to the complication rate, as well as to the development of new therapeutics (botulinum toxin, etc.) and directions for research (spinal cord stimulation) that may have an impact on people. Nevertheless, the lack of alternatives in the short-term suggests that the SARS implant is still relevant for the restoration of visceral functions after SCI.

\section{$\underline{\text { Introduction }}$}

Spinal cord injuries (SCI) have disastrous consequences for individuals, who, in addition to the motor impairments, must deal with sexual, bowel and urinary problems. Beyond their impact on health, these disorders have psychosocial implications that must not be neglected. Regarding lower urinary tract (LUT) function, SCI results in a communication breakdown between supraspinal and spinal levels that not only manifests by the loss of voluntary control of micturition but also by an exacerbation of reflex processes. Adult neurogenic lower urinary tract dysfunction (ANLUTD) refers to the urological symptoms associated with these disturbances and expresses clinically by two major problems: the disruption of the detrusor activity (detrusor overactivity - DO or detrusor underactivity - DU) and the detrusor sphincter dyssynergia (DSD).

In order to restore urinary function, a device based on a strategy of functional electrical stimulation (FES) - more specifically, sacral anterior root stimulation (SARS) - was developed 40 years ago (implantation of the first person in 1976 and entering into the market in 1982) (1): the Brindley-Finetech® implant (or SARS implant). Stimulation electrodes are 
surgically disposed on S2 to S5 sacral anterior roots - i.e., roots composed of pelvic motor axons - and the device exploits the anatomical and physiological characteristics of the urinary tract to induce micturition. The detrusor being made up of slow dynamic smooth muscle fibers and the external urethral sphincter of fast dynamic striated muscle fibers; post-stimulus voiding is enabled by applying intermittent electrical stimulation. Indeed, at each stimulation cycle ( 3 seconds stimulation at $25 \mathrm{~Hz}$ followed by 6 seconds rest), the detrusor and the striated sphincter simultaneously contract and then relax asynchronously (striated sphincter relaxes instantly while detrusor contraction persists for a short time); this asynchrony is the source of a pressure gradient favorable to micturition. Default stimulation parameters - ie bladder-specific settings - might subsequently be adapted to either facilitate defecation (lengthening of stimulation cycles -10 secs on then 20 secs off) or sustained erection in male individuals (decrease of stimulation frequency at either 8 or $12 \mathrm{~Hz}$ ).

However, the Brindley device does not handle DO by itself as bladder contractions at low filling are still likely induced by the disturbed sacral reflex arch. Sacral deafferentation (i.e., sectioning of the sacral posterior roots, procedure called rhizotomy) is often coupled with SARS implantation to prevent DO - and, consequently, promote bladder compliance - but results in the potentially irreversible loss of spared perineal sensation and function (erection and ejaculation in men, vaginal lubrication in women, defecation).

Recent technological improvements paved the way to optimized sacral stimulation paradigms likely to renew the interest for SARS-like approaches. In this context, reviewing the impact of Brindley implantation in patients with traumatic SCI seems an important step towards development of upgraded implants/strategies.

\section{$\underline{\text { Methods }}$}


We reviewed 40 years of Brindley implant use - from 1976 to 2020 - by analyzing the data in terms of i) visceral function results, ii) occurrences of adverse effects, iii) quality of life impact/considerations, and iv) additional aspects, especially long-term concerns - e.g., impact of laminectomies on spinal stability or compatibility with MRI exams.

\section{$\underline{\text { Literature search }}$}

This systematic review was performed according to the Preferred Reporting Items for Systematic reviews and Meta-Analyses (PRISMA) recommendations. Three databases were searched: Pubmed (main database), EBSCOhost (medical database) and Pascal (European and French database) based on keywords selected by an engineer (TG) and a physician specialized in physical and rehabilitation medicine (CF). No language or date restrictions were applied and the last search was performed in August 2020. The search was carried out using the terms "sacral anterior root stimulator", "implantable neurostimulator", "neural prostheses", "electrical stimulation therapy", "neurogenic bladder", "urinary incontinence”, "urinary retention, "bowel function", "acceptability", "failures", "quality of life” and "psychology" confined to additional filters like "human species" and "adult" in Pubmed. The abstracts of all identified studies were screened by TG according to inclusion criteria defined with the senior authors. Only articles related to SARS in adults with SCI of traumatic origin were kept for analysis whatever their level of evidence (from cohort study to single subject design) or the number of implanted individuals (from large groups of persons to case study). TG then reviewed the selected articles in full text according to a review protocol designed in collaboration with CF, CA-C and DG. Manual inspection of the reference lists of all included papers was carried out to identify studies that were not captured by the online search (Figure 1) and senior authors undertook a repeat review to ensure inclusion of all relevant articles.

\section{$\underline{\text { Study selection }}$}


Evaluating the action of the SARS procedure implies assessing its impact in terms of improved visceral functions - LUT, defecation and erection - but also the risks inherent to implantation (surgery, technical failures, etc.). The impact of SARS on quality of life was also investigated in this literature review, as were several additional findings on long-term followup (compatibility with MRI exams, etc.).

Studies from the same research group were carefully inspected and only studies with significantly different numbers of individuals, sufficient temporal gaps and different population characteristics were kept for the first analysis. Two-part studies were treated separately when they reported results in two different axes of research.

\section{$\underline{\text { Raw data extraction and presentation }}$}

First, the main characteristics of each paper were extracted. The nature of the article (retrospective, prospective study, case study etc.), the year of publication and the main features of the investigated population (number of individuals, age, type of lesions, etc.) were examined. The level of evidence and the risk of bias were assessed at the same time using the recommendations of the Oxford Centre for Evidence-Based Medicine and the Cochrane's Risk of Bias in Non-randomized Studies of Interventions (ROBINS-I) tool (2) respectively.

The article contents were analyzed through four reading grids, one for each axis, and the following information was extracted and combined in a table format:

- Urological, intestinal, and sexual benefits: use of the SARS implant for micturition, defecation and sexual purposes; bladder volume; volume of residual urine; incontinence episodes; urinary tract infections; autonomic dysreflexia before and after surgery. 
- Implantation procedure and reliability: sacral deafferentation and implantation procedure; complications following surgery; implant failures; impact on peoples' everyday lives and long-term side effects; other considerations (benefits, etc.).

- Individuals' quality of life: population; survey modalities; results.

- Studies providing additional information.

\section{Data analysis}

Given the large amount of generated data and in order to avoid patient redundancy, articles authorships as well as medical centres location were extracted from each paper before grouping them by geographic areas - Austria, France, Germany, Netherlands, North America, South America, Spain, Switzerland and United Kingdom (Table 1, 2 and 3) - allowing for a better tracking of implanted individuals for advanced analysis. For the same medical centre, according to their level of evidence and bias, articles were primarily used for main analysis or only for data completion precluding multiple computation of data from a single individual. In the same way, only publication stating data from the same individuals before and after implantation were used for computation of urologic outcomes while data from multicentric studies - including the three articles authored by GS Brindley - were reported separately. Last, the mean values of the most salient variables in each of these table were calculated on the generated dataset in order to obtain a summary statement of the literature.

\section{$\underline{\text { Statistical analysis }}$}

When available, standard deviations associated with pre- and post-implantation bladder and residual urine volumes were extracted for statistical analysis. After ensuring independence between study-level variances and sample sizes (plots of squared standard deviation versus sample size complemented with a monotony assessment using a spearman coefficient), 
inverse variance weighting was used to implement both a fixed effect and a random effect meta-analytic model (Hunter and Schmidt model [HSM] (3)). Indicators of heterogeneity $\mathrm{H}^{2}$ and $\mathrm{I}^{2}$ provided insights upon models' relevance and confirmed the validity of the HSM model. After obtaining the meta-analysis global estimates and standard errors, $95 \%$ confidence interval values were drawn from a t-distribution (t-score being more conservative than z-score). For qualitative indicators - presence/absence of UTI or incontinent episode, statistics were drawn from a t distribution after comparison of pre and post implantation ratios. $95 \%$ confidence intervals were then used to determine significance for $\alpha=5 \%$. These statistical analyses were carried out using the Metalab toolbox developed in Matlab (4).

\section{Results}

\section{$\underline{\text { Research process and study design }}$}

The flow diagram of the literature search is shown in Figure 1. At the end of the selection process, 38 articles were retained for analysis including 24 retrospective studies (5-28), 4 prospective studies (29-32), 4 cross-sectional studies (33-36), 4 case reports (37-40), 1 survey (41) and 1 basic research article (42).

Among these publications, 6 dealt with individuals quality of life $(29,30,33-36)$, and 8 others - including two case reports - were placed in the category "Other considerations" $(5,6,37-$ 42). The axes "Benefits for visceral functions" and "Implantation procedure and reliability" regrouped the 24 remaining publications.

The raw data from these studies were compiled in a table format - five tables in total, one combining the population characteristics plus one for each axis of investigation (Supplementary Tab.1, Supplementary Tab.2, Supplementary Tab.3, Table 4 and Table 5). Among these 38 publications, data from 4 multicentric studies (Supplementary Table 4) were 
subsequently withdrawn from analysis $(15-17,22)$ as they were grouping results from several medical centers and precluded individualized follow-up.

Two additional figures investigated the risk of bias (Supplementary Fig.1) and the level of evidence (Supplementary Fig.2) of these studies. Interestingly, a gradual shift was observed from visceral benefits and implant reliability to quality of life issues over the last decades while wider considerations such as the long-term outcome of implanted persons emerged rather recently (Supplementary Fig.2).

\section{$\underline{\text { Data analysis }}$}

A total of 1,147 implanted persons were tracked in 34 articles including 712 men and 435 women (Table 1). Individuals' mean age at the time of implantation was 36 years (ranged between 26.3 and 40 years, $n=1,091)$ while 467 (31.3\%) persons had tetraplegia and 680 (68.7\%) paraplegia. The mean time between spinal injury and implantation was 8.45 years (varied from 1.86 to 11.17 years, $\mathrm{n}=1,097$ ) and the mean post-implantation follow-up was 12.3 years (between 4.4 and 14.6 years, $n=957$ ). Implantations were performed on people with complete SCI in $88.9 \%$ [77-100\%] of cases (mean [range of the means by geographical areas], $\mathrm{n}=1124)$.

\section{$\underline{\text { Benefits for visceral functions }}$}

The impact of the Brindley implant on urinary, intestinal and sexual functions was initially reported in 24 studies. Of these 24 studies, $50 \%$ were ranked as level II or III, while the remaining $50 \%$ were categorized as level IV or V (Table 2).

Among the 1,147 individuals identified with SARS implant, 880 individuals were asked for their current situation and $85.9 \%$ [73-100\%] stated using their implant for micturition. Their averaged bladder capacity significantly increased from $198 \mathrm{~mL}$ [173-264 mL] before 
implantation to $480 \mathrm{~mL}$ [401-546 mL] (n=751) after implantation (HSM for 295 individuals $(10,17,19,30,32)$ : mean increase in bladder volume $=279 \mathrm{~mL} ; 95 \%$ Confidence Interval $[\mathrm{CI}]$, +191 to $+354 \mathrm{~mL}$ ), whereas the mean volume of residual urine after micturition decreased significantly from $131 \mathrm{~mL}$ [90-157 mL] $(\mathrm{n}=57)$ to $46 \mathrm{~mL}$ [16-85.7 mL] (HSM for 72 people $(11,12,17,30)$ : mean decrease in residual urine $=-97 \mathrm{~mL} ; 95 \% \mathrm{CI},-71$ to $-122 \mathrm{~mL})$. Urinary incontinence affected $86 \%$ [61-100\%] and 35.5\% [7-65\%] of the individuals before and after implantation respectively $(\mathrm{n}=691$; $\mathrm{t}$-distribution, $\mathrm{p}<0.05)$. Urinary tract infections decreased from 6.3 to 1.3 episodes per year in the German group $(n=464)$ while the overall percentage of persons affected by urinary tract infections in other areas dropped from 93\% [87.7-100\%] to $39 \%[15-78 \%](\mathrm{n}=402$, t-distribution, $\mathrm{p}<0.05)$.

In addition to the LUT data, $67.9 \%$ [29-100\%] of the patients $(n=654)$ used their implant to facilitate bowel movements, while $62.1 \%$ [30-100\%] of the male individuals ( $n=143$ of 230 males) were able to obtain stimulation-induced erections. Finally, the proportion of individuals with autonomic dysreflexia decreased from $43.3 \%$ [16-66\%] to $3 \%$ [0-9\%] after implantation $(\mathrm{n}=895)$.

\section{$\underline{\text { Implantation procedure and reliability }}$}

SARS implant reliability and impact on individuals with SCI was assessed by five modalities:

i) nature of the surgical procedure, ii) surgical complications, iii) implant failures, iv) longterm complications, and v) additional information (benefits of the implantation, problems using the implant, etc.). The corresponding data were drawn from 22 publications gathering 989 implanted individuals from 10 level II or III studies - 45.5\% - and 12 level IV or V publications $-54.5 \%$ (Table 3 ).

In $83.3 \%$ of individuals, Brindley devices were implanted intradurally. Sacral deafferentation was attempted in $99.4 \%$ of cases with a success rate of $93.9 \%$. A total of 34 immediate post- 
surgical complications occurred after the initial surgery $(3.4 \%$ - infections, cerebrospinal fluid leakage, etc.). Adverse effects caused by the implant/stimulation were reported in 54 cases (5.5\%: muscle spasms, stimulus pain, infections, etc.), whereas 209 implant faults $(21.1 \%$ of implants) were reported leading to 136 revision surgeries (surgeries to replace implant failures: $13.7 \%)$. Last, the SARS procedure proved to be insufficient in 63 persons $(6.3 \%)$ who faced persistent urinary disorders (incontinence, sphincterotomy, etc.).

Nevertheless, the cleanest database on the subject remains Brindley's 1995 publication overviewing the 500 first implanted individuals (8) (Supplementary Tab.4).

\section{$\underline{\text { Patient quality of life }}$}

Six publications were classed in this axis (Table 4; 488 individuals: 138 from level II and 350 from level III studies). In a nutshell, two distinct groups emerged and the conclusions drawn by Wielink et al. (29), Vastenholt et al. (33) and Rasmussen et al. (35) differed slightly from those of Creasey et al. (30), Martens et al. (34) and Zaer et al. (36).

For Wielink et al. (29) and Vastenholt et al. (33), implantation had an overall beneficial impact on individuals but this improvement was either not statistically significant (Wielink et al. (29)) or concerned only half the persons (people expectations met in $49 \%$ of cases in Vastenholt et al. (33)). Rasmussen et al. (35), for their part, only assessed quality of life related to bowel function in implanted individuals with no real improvement.

Conversely, no reservation was expressed about the positive impact of implantation in Creasey et al. (30)(improvement in $86.8 \%$ of the cases), Martens et al. (34) (results from Qualiveen and SF-36 questionnaire) and Zaer et al. (36) (overall satisfaction of implanted individuals and improvements of bladder function), for which a clear improvement in individual's quality of life was demonstrated. 
Eight publications were retained to complement this review as they were dealing with aspects little or not documented in previous studies (Table 5; 204 individuals from level IV or V studies including 4 case studies). Among these papers, six dealt directly with the consequences of implantation $(5,6,37-40)$, while the last two $(41,42)$ were focused on the prospects of this design of implant.

Lopez de Heredia et al. (5) concluded on the safety of MRI examination in implanted persons when conducting examinations in a 1.5 Tesla system - a central concern for the follow-up of people with SCI. Krebs et al. (6) showed no significant alteration of bladder contraction during stimulation-induced micturition in 111 patients 11.7 years after implantation.

Conversely, Soni et al. (37) questioned the long-term impact of laminectomy on spinal balance by reporting fractures of L4 and L5 vertebral bodies in one patient that induced a deterioration in his condition eventually leading to the cessation of implant use. Vaidyanathan et al. (38) and Bramall et al. (40) reported implant infections with complete removal of the device while Pannek et al. (39) reported the case of a patient with life-threatening autonomic dysreflexia for whom sacral deafferentation was necessary but who refused SARS implantation - raising genuine questions about the psychological impact of neuroprosthetic implantation.

Dealing with the future of the SARS implant, Kirkham et al. (42) investigated simultaneous stimulation of both anterior and posterior roots to restore LUT function without sacral deafferentation but concluded to the failure of the investigated procedure while Sanders et al. (41) attempted to identify patients' preferences for future neuroprostheses and highlighted the major role of the benefit-risk ratio on implant acceptability.

\section{$\underline{\text { Discussion }}$}




\section{Level of evidence}

This systematic review gathered 1,147 implanted individuals from 34 publications. These 34 articles presented unequal levels of evidence (studies with a control group/level II: 2; prospective studies/level III: 11; retrospective studies/level IV: 11; case studies and short communications/level V: 10) as well as unequal risk of bias (supplementary Fig.1).

The number of publications classed under each axis of research proved also highly variable (Supplementary Fig.2). Most of the collected data related either to clinical results on visceral functions $(n=24)$ or implant reliability $(n=22)$. Only a few dealt with quality of life $(n=6)$, although these studies had the highest level of evidence (level II or III) while long-term considerations were often limited to low-evidence articles (8 articles: levels IV or V including 4 case studies).

\section{$\underline{\text { Assessment of Brindley implantation }}$}

a) Benefit/risk balance

For all clinical examinations - bladder capacity, volume of residual urine, incontinence episodes, urinary infections, facilitation of bowel movements, autonomic dysreflexia - a gain of function was systematically observed as a results of a combined SARS and sacral deafferentation procedure in all the investigated studies (Table 2).

Apart from the imponderables of such a procedure - i.e., surgery, electronic device implantation and sacral deafferentation - discomfort resulted mostly from surgical complications or implant failures that were corrected spontaneously (leak of cerebrospinal fluid, neuropraxia etc.) or after a second surgery (cable replacement, second extradural implantation) (Table 3). Deafferentation was responsible for constipation or erectile dysfunction but had a rather unpredictable impact on fecal incontinence; promoting stress 
incontinence of feces - by reducing reflex contraction of the anal sphincter - in one hand or decreasing fecal incontinence by reducing bowel reflex contractions in the other hand.

The aging of the implanted population raised previously unknown issues, such as the impact of laminectomy on spine balance or the safety of MRI exams (implant successfully tested with 1.5 Tesla MR System (5) while manufacturer documentation reports safe procedures with $>0.5$ Tesla machines). Brindley also reported two death in his follow-up of the first 500 implanted individuals $(7,8)$ - one due to renal failure and the other from primary bladder carcinomatosis (Supplementary Tab.3) - but none was mentioned in the 34 retained studies.

As patients' expectations for the implant are often very high - and legitimately so - these unexpected drawbacks might have engendered frustration despite the overall success of the procedure. This might explain the results - globally positive but somewhat contrasted - of quality of life studies (Table 4).

b) Decline in the use of the implant

In addition to the SARS implant, other competing solutions - surgical and drug approaches emerged in recent years offering patients and medical staff several therapeutic alternatives especially to treat refractory DO (43). Surgical solutions include augmentation enterocystoplasty and/or continent cystostomy and offer the advantage of achieving both sustainable results and an optimal action on DO but constitute unique invasive procedures. Medication approaches may also be prescribed such as semi-invasive botulinum toxin injections. However, repeated injections are needed to achieve a significant decrease in DO emphasizing the transient impact of this procedure and the discontinuous nature of the generated effect - discontinuity that generates discomfort in patients waiting for renewal of the injection. Finally, both botulinum toxin and surgical approaches do not enable patients to get away from intermittent (self-) catheterization to manage DSD issues. 
From an economic perspective, additional reports concluded the cumulative cost of treatment with the neuroprosthesis - including the cost of the device, its implantation and maintenance to be equaled of those of conventional care on a time horizon between 5- and 8-years postimplantation (comparison before and after implantation $(29,44)$ ). Subsequent studies further investigated the cost-effectiveness ratio of the SARS approach to deeply inform decision makers of the opportunity to reimburse this procedure (versus a control group $(45,46))$ and provided recommendations in favor of the Finetech-Brindley implant. Nevertheless, these conclusions were a bit contrasted by the mixed results reported in studies focused on the quality of life of the implanted population (29,30,33-36). Thus, in the vast majority of cases, the cost of the procedure is still largely borne by patients while some alternatives are cheaper on a shorter term and more easily reimbursed by the health care system. This lead to a potentially insurmountable financial burden on interested individuals that will dissuade them from opting for the neuroprosthesis and may further explain, at least in part, the decline in implantation. Likewise, the gradual decline in implantation leads to a reduction in trained surgical services and to an even greater reduction in the number of prescriptions making this approach slowly falling back into anonymity.

Beyond the aforementioned factors, the rise of the Internet facilitates public access to recent scientific advances and raises expectation for the development of a medium-term comprehensive solution (stem-cell therapy, neuroprosthesis etc.). Patients are therefore more likely to preserve their "neurological capital" - and so to reject any deafferentation - and to suspend all surgical procedures while waiting for this new solution.

Distrust of some patients with regard to the implantation of electronic devices for ideological considerations may also constitute a limiting factor.

c) Targeted population 
SARS is therefore one of the solutions to overcome visceral deficiency but by both its nature and the incidence of adverse effects, the generalization of its recourse is unlikely; secondary ejaculatory dysfunction and loss of sensitivity already precluding deafferentation in persons with incomplete lesions. However, since the population of patients with a spinal cord injury is very disparate - particularly with respect to the lesion profiles or the age of the individuals SARS implant may still be relevant for certain categories of patients:

- $\quad$ Aging patient with paraplegia or tetraplegia (woman or man) in trouble to continue self-catheterization.

- Women with paraplegia or tetraplegia, able to perform self-catheterization, to transfer and to undress but confronted with residual incontinence (DO - different form stress incontinence) that cannot be collected by a specific device equivalent to the penile sheath in men.

- Women or men with paraplegia or tetraplegia who can no longer or cannot apply intermittent self-catheterization due to overweight or obesity.

- Patient with paraplegia or tetraplegia (woman or man) who refuses self-catheterization for practical reasons or to avoid urinary tract infections.

Although ANULTD management is very much dependent on the patient's medical condition and willingness, several studies have helped to deeply revise the current therapeutic arsenal to provide easy-to-follow treatment guidelines applicable to large cohorts of patients. Based on the objective to be achieved: i) continence with intermittent catheterization, ii) continence without catheterization, or iii) reflex micturition, several therapeutic stratagems might be implemented to help patients with DO or DSD - see Denys et al (47), Wyndaele et al (48) or Anquetil et al (43) for more details. Nevertheless, it might be worth complementing these 
guidelines by mentioning that Brindley implantation is not precluding future urological surgeries when, conversely, prior urological intervention is likely to prevent SARS procedure.

\section{$\underline{\text { Study limitations }}$}

The lack of randomized or multi-group studies reduced the level of certainty of this systematic review. This situation can be explained by the difficulty of setting up randomized protocols because of both the invasiveness of surgery and people high expectations about implantation. It might also be due to the relative paucity of complete spinal cord injury as examiners might have anticipated that such a randomization would had decrease their recruitment potential. Similarly, setting up cross-over studies seems very unlikely because of the sacral deafferentation. Most of the publications on SARS have come from neurosurgical departments and, unsurprisingly, many of these studies dealt exclusively with urological and surgical outcomes, while few focused on patient quality of life.

As the selected studies were performed at different location across the globe, differing surgeries, post-surgical treatment care and rehabilitation may have affected outcomes. Only few studies reporting fragmentary data were thus available for individuals implanted in Spain or United Kingdom. Absence of a systematic report of pre and post-surgery data - as well as their respective variances - further undermine the impact of our conclusions by drastically reducing the number of implanted people eligible for final analysis. Discrepancies in followup periods and reporting procedures, especially regarding postoperative complication/care and quality of life assessment, also make synthetizing these data extremely difficult - our study is, to the best of our knowledge, the first systematic review on the SARS implant. In the same way, as this literature review extending over four decades, both the surgical approach and the implant reliability were continuously refined for the succeeding studies. Originally implanted without deafferentation, outcomes of the first/pioneer studies were likely impacted by the 
preservation of a disturbed sacral reflex arch in some individuals while management of side effects has progressively improved over time. Ultimately, as patient long term follow-up is often ensured by clinical centers close to the patients' homes, long-term assessment of large cohorts of individuals remains a challenge. It is therefore not surprising that most of the publications related to long-term implantation consequences are case studies.

\section{$\underline{\text { Future directions }}$}

The main limitation of the implantation procedure remains the systematic posterior root rhizotomy. New stimulation strategies are currently studied to bypass this procedure and are mainly based on direct spinal cord stimulation $(49,50)$ or on a combination of spinal roots and pudendal nerve stimulation. These main approaches are the so called "LION approach" (51), the sphincter fatigue procedure $(52)$, the blocking technique $(53,54)$ and the high frequency technique (55).

\section{Conclusions}

Despite generally positive results on visceral functions - especially LUT function - the number of Brindley implantation procedures has declined in recent years. Although the risks inherent to this procedure was minimized, the emergence of mini-invasive therapeutic alternatives such as botulinum toxin therapy has limited its use. The deafferentation coupled with the implantation procedure dissuades many persons frightened by its very invasive nature. However, sacral deafferentation might still constitute a valid alternative in individuals with a botulinum toxin-resistant bladder and might still be considered in competition with more widespread urological surgeries such as enterocystoplasty. 
The rehabilitation of visceral functions remains a major concern of individuals with SCI, and thus many research teams are dedicated to finding less invasive solutions or alternatives that are likely to offer these persons a dramatic gain in quality of life. Nonetheless, the lack of alternatives in the short term suggests that the SARS and SARS-like implants are still relevant within the therapeutic arsenal.

\section{Data Archiving}

All data generated or analysed during this study are included in this published article.

\section{Acknowledgments}

The authors would like to thank Christine Gilbert for her help in the literature search.

\section{Conflict of Interest Statement}

The authors report no conflict of interest concerning the materials or methods used in this study or the findings specified in this paper.

\section{$\underline{\text { Author Contributions }}$}

TG was responsible for designing the review protocol, conducting the search, screening potentially eligible studies, extracting and analyzing data, interpreting results, creating tables, and writing the report.

CF was responsible for designing the review protocol, conducting the search and assessing potentially eligible studies. He contributed to writing the report and interpreting results.

CAC and DG contributed to the review protocol and provided feedback on the report.

$\mathrm{CD}, \mathrm{LB}, \mathrm{JRV}$ interpreting results and provided feedback on the report. 


\section{$421 \quad$ Funding}

422 This work was carried out with the support of the I-SITE MUSE, Companies on Campus 423 program (SPINSTIM project - AAP18ENT-FRM06-SPINSTIM) and an ERANET Neuron 424 joint call co-funded by the Medical Research Council (R001189). The Companies on Campus 425 program financed the SPINSTIM project and the ERANET call financed Thomas Guiho.

\section{$427 \quad$ References}

428 1. Brindley GS. History of the sacral anterior root stimulator, 1969-1982. Neurourol $429 \quad$ Urodyn. 1993;

430

2. McGuinness LA, Higgins JPT. Risk-of-bias VISualization (robvis): An R package and Shiny web app for visualizing risk-of-bias assessments. In: Research Synthesis Methods. 2021;

3. Hunter J, Schmidt F. Methods of meta-analysis: Correcting error and bias in research findings. https://books.google.fr/books. 2004;

4. Mikolajewicz N, Komarova S V. Meta-Analytic Methodology for Basic Research: A Practical Guide. Front Physiol. 2019;

5. Lopez De Heredia L, Meagher TMM, Jamous MA, Hughes RJ. Long-term effect of MRI on sacral anterior root stimulator: The Stoke Mandeville experience. Spinal Cord. 2012;

6. Krebs J, Wöllner J, Grasmücke D, Pannek J. Long-term course of sacral anterior root stimulation in spinal cord injured individuals: The fate of the detrusor. Neurourol Urodyn. 2017; 
443 7. Brindley GS. The first 500 patients with sacral anterior root stimulator implants: General description. Paraplegia. 1994;

445 8. Brindley GS. The first 500 sacral anterior root stimulators: Implant failures and their repair. Paraplegia. 1995;

447 9. Van Kerrebroeck PEV, Koldewijn EL, Rosier PFWM, Wijkstra H, Debruyne FMJ. Results of the treatment of neurogenic bladder dysfunction in spinal cord injury by sacral posterior root rhizotomy and anterior sacral root stimulation. J Urol. 1996;

10. Egon G, Barat M, Colombel P, Visentin C, Isambert JL, Guerin J. Implantation of anterior sacral root stimulators combined with posterior sacral rhizotomy in spinal injury patients. World J Urol. 1998;

11. Schurch B, Knapp PA, Jeanmonudj D, Rodic B, Rossler AB. Does sacral posterior rhizotomy suppress autonomie hyper-reflexia in patients with spinal cord injury? Br J Urol. 1998;

12. Van Der Aa HE, Alleman E, Nene A, Snoek G. Sacral anterior root stimulation for bladder control: Clinical results. Arch Physiol Biochem. 1999;

13. Bauchet L, Segnarbieux F, Martinazzo G, Frerebeau P, Ohanna F. Traitement neurochirurgical de la vessie hyperactive chez le blessé médullaire. 2001;13-24.

14. Sauerwein DS. Sacral deafferentation with implantation of an anterior root stimulator. Experience after 15 years in 430 patients. Eur Urol Suppl. 2003; 
16. Kutzenberger J, Domurath B, Sauerwein D. Spastic bladder and spinal cord injury: Seventeen years of experience with sacral deafferentation and implantation of an anterior root stimulator. Artif Organs. 2005;

17. Madersbacher H, Fischer J, Ebner A. Anterior sacral root stimulator (Brindley): Experiences especially in women with neurogenic urinary incontinence. Neurourol Urodyn. 1988;

18. Kutzenberger J. Surgical therapy of neurogenic detrusor overactivity (hyperreflexia) in paraplegic patients by sacral deafferentation and implant driven micturition by sacral anterior root stimulation: Methods, indications, results, complications, and future prospects. Acta Neurochirurgica, Supplementum. 2007.

19. Krasmik D, Krebs J, Van Ophoven A, Pannek J. Urodynamic results, clinical efficacy, and complication rates of sacral intradural deafferentation and sacral anterior root stimulation in patients with neurogenic lower urinary tract dysfunction resulting from complete spinal cord injury. Neurourol Urodyn. 2014;

20. Castaño-Botero JC, Ospina-Galeano IA, Gómez-Illanes R, Lopera-Toro A. Extradural implantation of sacral anterior root stimulator in spinal cord injury patients. Neurourol Urodyn. 2016;

21. Ramos LV, Illanes* RG, Pantoja RC. MP48-09 EXPERIENCE WITH SARS (SACRAL ANTERIOR ROOT STIMULATOR) IN SUPRASACRAL SPINAL CORD INJURY PATIENTS. J Urol. 2020;

22. ROBINSON LQ, GRANT A, WESTON P, STEPHENSON TP, LUCAS M, THOMAS DG. Experience with the Brindley Anterior Sacral Root Stimulator. Br J Urol. 1988;

23. Brindley GS, Rushton DN. Long-term follow-up of patients with sacral anterior root 
stimulator implants. Paraplegia. 1990;

24. Sauerwein D, Ingunza W, Fischer J, Madersbacher H, Polkey CE, Brindley GS, et al. Extradural implantation of sacral anterior root stimulators. J Neurol Neurosurg Psychiatry. 1990;

25. Barat M, Egon G, Daverat P, Colombel P, Guerin J. Why does continence fail after sacral anterior root stimulator? Neurourol Urodyn. 1993;

26. Egon G, Colombel P, Isambert JL, Guerin J, Barat M. Evolution of bladder contraction in course of time after implantation of a sacral anterior root stimulator. Neurourol Urodyn. 1993;

27. Madersbacher H, Fischer J. Sacral anterior root stimulation: Prerequisites and indications. Neurourol Urodyn. 1993;

28. Sarrias M, Sarrias F, Borau A. The "Barcelona" technique. Neurourol Urodyn. 1993;

29. Wielink G, Essink-Bot ML, Van Kerrebroeck PEV, Rutten FFH, Bosch JLHR, Debruyne FMJ, et al. Sacral rhizotomies and electrical bladder stimulation in spinal cord injury. 2. Cost-effectiveness and quality of life analysis. Eur Urol. 1997;

30. Creasey GH, Grill JH, Korsten M, U HS, Betz R, Anderson R, et al. An implantable neuroprosthesis for restoring bladder and bowel control to patients with spinal cord injuries: A multicenter trial. Arch Phys Med Rehabil. 2001;

31. MacDonagh RP, Sun WM, Smallwood R, Forster D, Read NW. Control of defecation in patients with spinal injuries by stimulation of sacral anterior nerve roots. Br Med J. 1990;

32. Van Kerrebroeck E V, van der Aa HE, Bosch JL, Koldewijn EL, Vorsteveld JH, 
Debruyne FM. Sacral rhizotomies and electrical bladder stimulation in spinal cord injury. Part I: Clinical and urodynamic analysis. Dutch Study Group on Sacral Anterior Root Stimulation. Eur Urol. 1997;

33. Vastenholt JM, Snoek GJ, Buschman HPJ, Van Der Aa HE, Alleman ERJ, Ijzerman MJ. A 7-year follow-up of sacral anterior root stimulation for bladder control in patients with a spinal cord injury: Quality of life and users' experiences. Spinal Cord. 2003;

34. Martens FMJ, den Hollander PP, Snoek GJ, Koldewijn EL, van Kerrebroeck PEV a, Heesakkers JPF a. Quality of life in complete spinal cord injury patients with a Brindley bladder stimulator compared to a matched control group. Neurourol Urodyn. 2011;30(4):551-5.

35. Rasmussen MM, Kutzenberger J, Krogh K, Zepke F, Bodin C, Domurath B, et al. Sacral anterior root stimulation improves bowel function in subjects with spinal cord injury. Spinal Cord. 2015;

36. Zaer H, Rasmussen MM, Zepke F, Bodin C, Domurath B, Kutzenberger J. Effect of spinal anterior root stimulation and sacral deafferentation on bladder and sexual dysfunction in spinal cord injury. Acta Neurochir (Wien). 2018;

37. Soni BM, Oo T, Vaidyanathan S, Hughes PL, Singh G. Complications of sacral anterior root stimulator implantation in a cervical spinal cord injury patient: Increased spasms requiring intrathecal baclofen therapy followed by delayed fracture of lumbar spine leading to intractable spasms compelling disuse of. Spinal Cord. 2004.

38. Vaidyanathan S, Soni BM, Oo T, Hughes PL, Mansour P, Singh G. Infection of Brindley sacral anterior root stimulator by Pseudomonas aeruginosa requiring removal 
of the implant: Long-term deleterious effects on bowel and urinary bladder function in a spinal cord injury patient with tetraplegia: A case report. Cases J. 2009;

39. Pannek J, Göcking K, Bersch U. Sacral rhizotomy: A salvage procedure in a patient with autonomic dysreflexia. Spinal Cord. 2010;

40. Bramall A, Chaudhary B, Ahmad J, Shamji MF. Chronic infection of a Brindley sacral nerve root stimulator. BMJ Case Rep. 2016;

41. Sanders PMH, Ijzerman MJ, Roach MJ, Gustafson KJ. Patient preferences for next generation neural prostheses to restore bladder function. Spinal Cord. 2011;

42. Kirkham APS, Knight SL, Craggs MD, Casey ATM, Shah PJR. Neuromodulation through sacral nerve roots 2 to 4 with a Finetech-Brindley sacral posterior and anterior root stimulator. Spinal Cord. 2002;

43. Anquetil C, Abdelhamid S, Gelis A, Fattal C. Botulinum toxin therapy for neurogenic detrusor hyperactivity versus augmentation enterocystoplasty: Impact on the quality of life of patients with SCI. Spinal Cord. 2016;

44. Creasey GH, Dahlberg JE. Economic consequences of an implanted neuroprosthesis for bladder and bowel management. Arch Phys Med Rehabil. 2001;

45. Morlière C, Verpillot E, Donon L, Salmi LR, Joseph PA, Vignes JR, et al. A costutility analysis of sacral anterior root stimulation (SARS) compared with medical treatment in patients with complete spinal cord injury with a neurogenic bladder. Spine J. 2015;

46. Bénard A, Verpillot E, Grandoulier AS, Perrouin-Verbe B, Chêne G, Vignes JR. Comparative cost-effectiveness analysis of sacral anterior root stimulation for 
rehabilitation of bladder dysfunction in spinal cord injured patients. Neurosurgery. 2013;

47. Denys P, Corcos J, Everaert K, Chartier-Kastler E, Fowler C, Kalsi V, et al. Improving the global management of the neurogenic bladder patient: Part II. Future treatment strategies. Current Medical Research and Opinion. 2006.

48. Wyndaele JJ, Birch B, Borau A, Burks F, Castro-Diaz D, Chartier-Kastler E, et al. Surgical management of the neurogenic bladder after spinal cord injury. World Journal of Urology. 2018.

49. Guiho T, Delleci C, Azevedo-Coste C, Fattal C, Guiraud D, Vignes JR, et al. Impact of direct epispinal stimulation on bladder and bowel functions in pigs: A feasibility study. Neurourol Urodyn. 2018;

50. Guiho T, Azevedo-Coste C, Andreu D, Delleci C, Bauchet L, Vignes JR, et al. Functional selectivity of lumbosacral stimulation: Methodological approach and pilot study to assess visceral function in pigs. IEEE Trans Neural Syst Rehabil Eng. 2018;

51. Possover M, Schurch B, Henle K-P. New strategies of pelvic nerves stimulation for recovery of pelvic visceral functions and locomotion in paraplegics. Neurourol Urodyn. 2010;29(8):1433-8.

52. Li JS, Hassouna M, Sawan M, Duval F, Elhilali MM. Long-Term Effect of Sphincteric Fatigue During Bladder Neurostimulation. J Urol. 1995;

53. Rijkhoff NJM, Wijkstra H, Van Kerrebroeck PEV, Debruyne FMJ. Selective detrusor activation by sacral ventral nerve-root stimulation: Results of intraoperative testing in humans during implantation of a Finetech-Brindley system. World J Urol. 1998; 
577 54. Peh WYX, Mogan R, Thow XY, Chua SM, Rusly A, Thakor N V., et al. Novel

578

579

580

581

582

583

584

585

586

587

588

589

590

591

592

593

594

neurostimulation of autonomic pelvic nerves overcomes Bladder-sphincter dyssynergia. Front Neurosci. 2018;

55. Boger A, Bhadra N, Gustafson KJ. Bladder voiding by combined high frequency electrical pudendal nerve block and sacral root stimulation. Neurourol Urodyn. 2008;

\section{Figure Legends}

Figure 1. Flow diagram of the literature search

Table 1. Study and patient characteristics per geographic areas

Table 2. Benefits for visceral functions (geographic areas)

Table 3. Implantation procedure and reliability axis

Table 4. Patient quality of life

Table 5. Additional information

\section{Supplementary Figure Legends}

Supplementary Fig.1. Cochrane's Risk of Bias in Non-randomized Studies of Interventions (ROBINS-I) plot 
595 Supplementary Fig.2 - Articles characteristics. a) Distribution of the selected publications

596 classified according to their topics and their year of publication, b) Strength of evidence of the

597 selected articles

598 Supplementary Tab.1. Study and patient characteristics (all studies)

599 Supplementary Tab.2. Benefits for visceral functions (all studies)

600 Supplementary Tab.3. Implantation procedure and reliability axis (all studies)

601 Supplementary Tab.4. Multicentric studies 

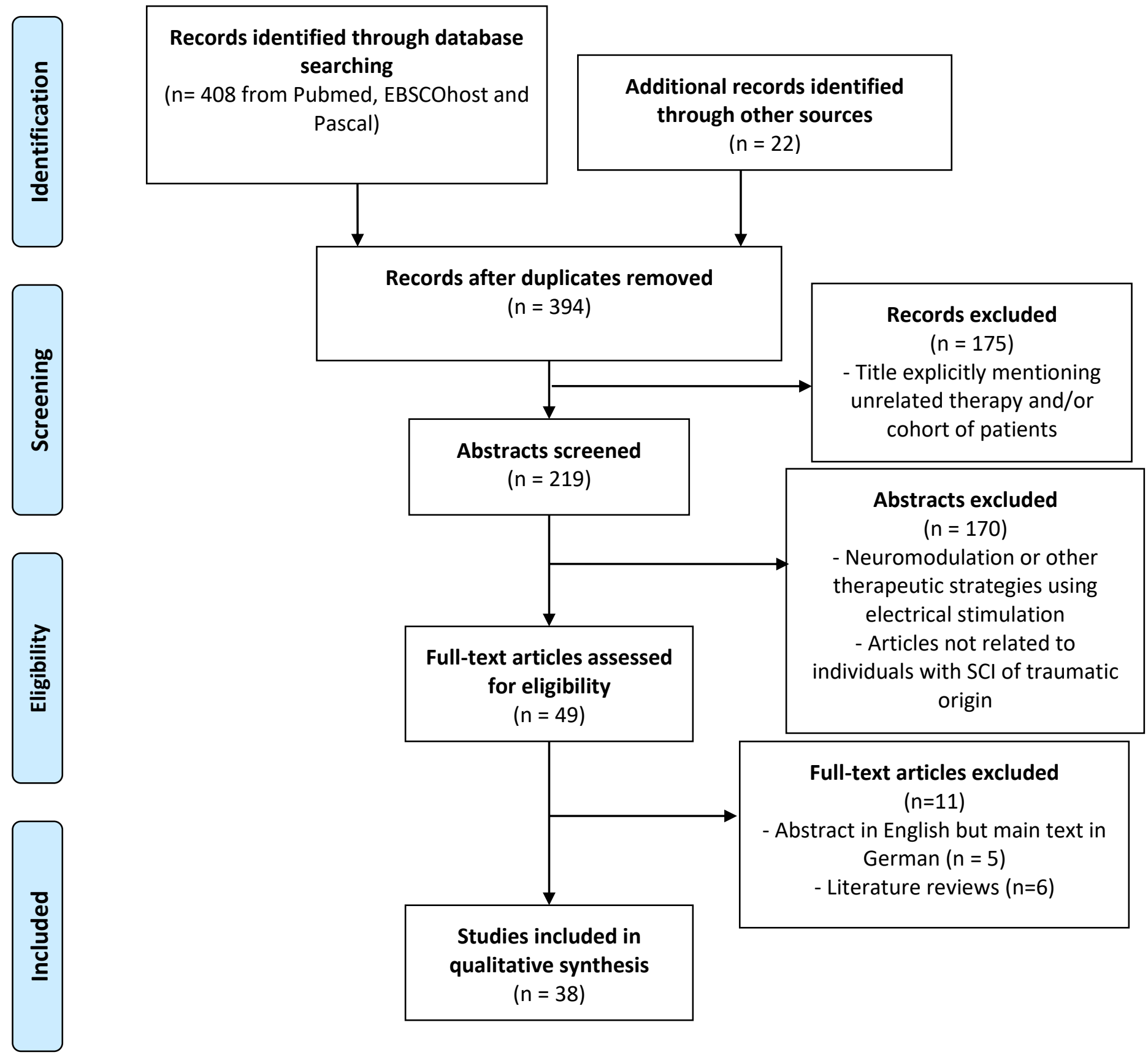

qualitative synthesis

$(n=38)$ 
Table 1 - Study and patients characteristics per geographic areas

\begin{tabular}{|c|c|c|c|c|c|c|c|c|}
\hline $\begin{array}{c}\text { Location } \\
\text { and period of } \\
\text { publication } \\
\text { [First to Last papers] }\end{array}$ & Identified groups & $\begin{array}{l}\text { References* and } \\
\text { level of evidence }\end{array}$ & $\%$ of male patient & $\begin{array}{c}\text { Mean age at the } \\
\text { time of } \\
\text { implantation } \\
\text { (in years) }\end{array}$ & $\begin{array}{l}\text { Lesion profile } \\
\text { T-Tetraplegia } \\
\text { P-Paraplegia }\end{array}$ & $\begin{array}{c}\text { \% of complete } \\
\text { SCl }\end{array}$ & $\begin{array}{l}\text { Mean age of the } \\
\text { lesion at the time of } \\
\text { implantation } \\
\text { (in years) }\end{array}$ & $\begin{array}{l}\text { Mean patient } \\
\text { follow up after } \\
\text { implantation } \\
\text { (in years) } \\
\end{array}$ \\
\hline $\begin{array}{c}\text { Austria } \\
\text { [1988-1993] }\end{array}$ & Innsbruck & $\begin{array}{l}\text { [Made88] - IV } \\
\text { [Made93]-V }\end{array}$ & $\begin{array}{c}27 \\
->n=30\end{array}$ & $\begin{array}{c}26.3 \\
->n=7\end{array}$ & $\begin{array}{l}\text { Trauma: } 30 \\
T-10 / P-20 \\
\quad>n=30\end{array}$ & $\begin{array}{c}97 \\
->n=30\end{array}$ & $\begin{array}{c}1.86 \\
->n=7\end{array}$ & $\begin{aligned} & <8 \\
-> & n=30\end{aligned}$ \\
\hline $\begin{array}{l}\text { United Kingdom } \\
\text { [1988-2012] }\end{array}$ & $\begin{array}{c}\text { Cardiff } \\
\text { Sheffield } \\
\text { Southport }\end{array}$ & $\begin{array}{c}\text { [Robi88] - IV } \\
\text { [MacD90] - III } \\
{[\text { Kirk02] - IV }} \\
{[\text { Soni04]-V }} \\
{[\text { Vaid09]-V }} \\
\text { [DeHe12]-IV } \\
\end{array}$ & $\begin{array}{c}91.75 \\
->n=24\end{array}$ & $\begin{array}{c}34.5 \\
\rightarrow n=2\end{array}$ & $\begin{array}{l}\text { Trauma: } 24 \\
T-9 / P-15 \\
\quad>n=24\end{array}$ & $\begin{array}{c}91.75 \\
->n=24\end{array}$ & $\begin{array}{c}4.96 \\
->n=24\end{array}$ & $\begin{array}{l}10.5 \\
\rightarrow n=2\end{array}$ \\
\hline $\begin{array}{c}\text { France } \\
{[1993-2004]}\end{array}$ & $\begin{array}{l}\text { Bordeaux } \\
\text { Le Mans } \\
\text { Montpellier } \\
\text { Nantes }\end{array}$ & $\begin{array}{l}\text { [Bara93] -V } \\
{[\text { Egon93]-V }} \\
\text { [Egon98]-IV } \\
{[\text { Bauc01]- III }} \\
{[\text { Hame04]-IV }}\end{array}$ & $\begin{array}{c}65.1 \\
->n=120\end{array}$ & $\begin{array}{c}33.6 \\
->n=116\end{array}$ & $\begin{array}{l}\text { Trauma: } 116 \\
\text { Unspecified: } 4 \\
T-48 / P-72 \\
\quad>n=120\end{array}$ & $\begin{array}{c}85.8 \\
->n=120\end{array}$ & $\begin{array}{c}6.6 \\
->\mathrm{n}=116\end{array}$ & $\begin{array}{c}5.34 \\
->n=116\end{array}$ \\
\hline $\begin{array}{c}\text { Spain } \\
\text { [1993] }\end{array}$ & Barcelona & [Sarr93]-V & $\begin{array}{c}14.3 \\
\rightarrow n=7\end{array}$ & - & $\begin{array}{c}\text { Trauma: } 7 \\
T-3 / P-4 \\
->n=7\end{array}$ & - & - & - \\
\hline $\begin{array}{l}\text { Netherlands } \\
\text { [1996-2011] }\end{array}$ & $\begin{array}{l}\text { Enschede } \\
\text { Nijmegen } \\
\text { Rotterdam }\end{array}$ & $\begin{array}{c}\text { [VanK96] - IV } \\
\text { [VanK97] - III } \\
\text { [Wiel97]- III } \\
\text { [VanD99] - III } \\
\text { [Vast03] - II } \\
\text { [Mart11] - II }\end{array}$ & $\begin{array}{c}68.6 \\
->n=89\end{array}$ & $\begin{array}{c}37.1 \\
->n=89\end{array}$ & $\begin{array}{l}\text { Trauma: } 89 \\
T-25 / P-64 \\
\quad>n=89\end{array}$ & $\begin{array}{c}100 \\
->n=89\end{array}$ & $\begin{array}{c}6.67 \\
->n=89\end{array}$ & $\begin{array}{c}4.8 \\
->n=89\end{array}$ \\
\hline $\begin{array}{l}\text { Switzerland } \\
\text { [1998-2017] }\end{array}$ & $\begin{array}{l}\text { Nottwil } \\
\text { Zurich }\end{array}$ & $\begin{array}{l}\text { Schu98] - III } \\
{[\text { Pann10] -V }} \\
{[\text { Kras14] - III }} \\
\text { [Kreb17]-IV } \\
\end{array}$ & $\begin{aligned} & 57.1 \\
&->n=147\end{aligned}$ & $\begin{array}{c}39.2 \\
->n=147\end{array}$ & $\begin{array}{l}\text { Trauma: } 147 \\
\begin{array}{c}T-58 / P-89 \\
\quad>n=147\end{array}\end{array}$ & $\begin{array}{c}95.9 \\
->n=147\end{array}$ & $\begin{array}{c}11.17 \\
->n=147\end{array}$ & $\begin{array}{c}14.05 \\
->n=147\end{array}$ \\
\hline $\begin{array}{l}\text { North America } \\
\text { [2001-2016] }\end{array}$ & $\begin{array}{c}\text { Cleveland } \\
\text { New York } \\
\text { Philadelphia } \\
\text { San Diego Stanford } \\
\text { Toronto } \\
\end{array}$ & $\begin{array}{l}\text { [Crea01] - III } \\
{[\text { Sand11] - IV }} \\
{[\text { Bram16] -V }}\end{array}$ & $\begin{array}{c}70 \\
->n=23\end{array}$ & $\begin{array}{c}40 \\
->n=23\end{array}$ & $\begin{array}{l}\text { Trauma: } 23 \\
T-6 / P-17 \\
\quad>n=23\end{array}$ & $\begin{array}{c}100 \\
->n=23\end{array}$ & $\begin{array}{c}7 \\
->n=23\end{array}$ & $\begin{array}{l}>1 \text { year but some } \\
\text { results are missing } \\
\quad \rightarrow n=23\end{array}$ \\
\hline $\begin{array}{c}\text { Germany } \\
\text { [2003-2018] }\end{array}$ & Bad Wildungen & $\begin{array}{l}\text { Saue03]-V } \\
{[\text { Kutz05]-IV }} \\
{[\text { Kutz07]- IV }} \\
{[\text { Rasm15]-III }} \\
{[\text { Zaer18]- III }} \\
\end{array}$ & $\begin{array}{c}57 \\
->n=587\end{array}$ & $\begin{array}{c}34.9 \\
->n=587\end{array}$ & $\begin{array}{c}\text { Trauma: } 561 \\
\text { Other specified causes: } \\
26 \\
T-266 / P-321 \\
\rightarrow n=587 \\
\end{array}$ & $\begin{aligned} & 84.5 \\
-> & n=587\end{aligned}$ & $\begin{array}{l}8.9 \\
->\mathrm{n}=587\end{array}$ & $\begin{aligned} & 14.6 \\
-> & n=587\end{aligned}$ \\
\hline $\begin{array}{l}\text { South America } \\
\text { [2016-2020] }\end{array}$ & $\begin{array}{c}\text { Medellin } \\
\text { Santiago de Chile }\end{array}$ & $\begin{array}{c}\text { [Cast16] - III } \\
{[\text { Ramo] -V }}\end{array}$ & $\begin{array}{c}89.2 \\
->n=120\end{array}$ & $\begin{array}{c}38.7 \\
->n=120\end{array}$ & $\begin{array}{c}\text { Trauma: } 103 \\
\text { Unspecified: } 17 \\
T-42 / P-78 \\
->n=120\end{array}$ & $\begin{array}{c}92.3 \\
\rightarrow n=104\end{array}$ & $\begin{array}{c}7.25 \\
->n=104\end{array}$ & $\begin{array}{c}4.4 \\
->n=16\end{array}$ \\
\hline
\end{tabular}

*References presented as the four first letters of the first author surname followed by the two last digits of the year of publication; -> $n=$ total number of implanted individuals with available information for each area 
Table 2 - Benefits on visceral functions (geographic areas)

\begin{tabular}{|c|c|c|c|c|c|c|c|c|c|c|c|c|c|}
\hline \multirow[t]{2}{*}{ Location } & \multirow{2}{*}{$\begin{array}{l}\text { Use of SARS } \\
\text { for } \\
\text { micturition } \\
\text { (\%) }\end{array}$} & \multicolumn{2}{|c|}{$\begin{array}{l}\text { Mean bladder } \\
\text { capacity } \\
\text { (volume in } \mathrm{ml} \text { ) }\end{array}$} & \multicolumn{2}{|c|}{$\begin{array}{l}\text { Mean residual urine } \\
\text { (volume in } \mathrm{ml} \text { ) }\end{array}$} & \multicolumn{2}{|c|}{$\begin{array}{l}\text { Incontinent episodes } \\
(\%)\end{array}$} & \multicolumn{2}{|c|}{ Urinary tract infections } & \multicolumn{2}{|c|}{$\begin{array}{l}\text { Autonomic dysreflexia } \\
(\%)\end{array}$} & \multirow{2}{*}{$\begin{array}{c}\text { Use for } \\
\text { defecation } \\
(\%)\end{array}$} & \multirow{2}{*}{$\begin{array}{c}\text { Use for } \\
\text { erection } \\
\text { (\% of } \\
\text { male) }\end{array}$} \\
\hline & & Before & After & Before & After & Before & After & Before & After & Before & After & & \\
\hline Austria & $\begin{array}{c}90 \\
->n=30\end{array}$ & $\begin{array}{c}209 \\
->n=7\end{array}$ & $\begin{array}{c}435 \\
->n=7\end{array}$ & $\begin{array}{c}116 \\
->n=7\end{array}$ & $\begin{array}{c}27 \\
->n=7\end{array}$ & $\begin{array}{c}100 \\
->n=30\end{array}$ & $\begin{array}{c}7 \\
->n=30\end{array}$ & - & $\begin{array}{c}0 \\
->n=7\end{array}$ & - & - & $\begin{array}{c}29 \\
->n=7\end{array}$ & $\begin{array}{c}100 \\
->n=1\end{array}$ \\
\hline United Kingdom & $\begin{array}{c}73 \\
->n=22\end{array}$ & - & - & - & - & - & $\begin{array}{c}32 \\
->n=22\end{array}$ & - & - & - & - & $\begin{array}{c}50 \text { (SARS } \\
\text { alone) } \\
->n=12\end{array}$ & $\begin{array}{c}30 \\
->n=20\end{array}$ \\
\hline France & $\begin{array}{c}89.7 \\
->n=116 \\
\end{array}$ & $\begin{array}{c}203 \\
->n=112 \\
\end{array}$ & $\begin{array}{c}546.4 \\
->n=112 \\
\end{array}$ & $\begin{array}{c}90 \\
->n=19 \\
\end{array}$ & $\begin{array}{c}25 \\
->n=19 \\
\end{array}$ & $\begin{array}{c}98.8 \\
->n=112 \\
\end{array}$ & $\begin{array}{c}11.58 \\
->n=112 \\
\end{array}$ & $\begin{array}{c}100 \\
->n=93\end{array}$ & $\begin{array}{c}29 \\
\rightarrow>n=93 \\
\end{array}$ & $\begin{array}{c}21.7 \\
->n=112 \\
\end{array}$ & $\begin{array}{c}0 \\
\rightarrow n=112 \\
\end{array}$ & $\begin{aligned} & 52.6 \\
&-> n=116 \\
&\end{aligned}$ & $\begin{array}{c}65.2 \\
->n=75 \\
\end{array}$ \\
\hline Spain & $\begin{array}{c}100 \\
->n=7\end{array}$ & - & $\begin{array}{c}>400 \text { in } \\
\text { all } \\
\text { patients } \\
->n=7\end{array}$ & - & $\begin{array}{c}<50 \text { in all } \\
\text { patients } \\
->n=7\end{array}$ & - & $\begin{array}{c}0 \\
->n=7\end{array}$ & - & - & - & - & $\begin{array}{c}100 \\
->n=7\end{array}$ & $\begin{array}{c}100 \\
->n=1\end{array}$ \\
\hline Netherlands & $\begin{array}{c}87.1 \\
->n=84\end{array}$ & $\begin{array}{c}285.4 \\
->n=52\end{array}$ & $\begin{array}{c}571.2 \\
->n=37\end{array}$ & $\begin{array}{c}104.7 \\
->n=52\end{array}$ & $\begin{array}{c}64.9 \\
\text { at one } \\
\text { year }-> \\
n=37\end{array}$ & $\begin{array}{c}90 \\
\text { (daytime) } \\
96 \text { (night) } \\
->n=52\end{array}$ & $\begin{array}{c}27 \\
\text { (daytime) } \\
14 \text { (night) at } \\
\text { one year } \\
->n=37\end{array}$ & $\begin{array}{c}98 \\
->n=37\end{array}$ & $\begin{array}{c}59 \\
->n=37\end{array}$ & $\begin{array}{c}15.9 \\
->n=47\end{array}$ & $\begin{array}{c}4.25 \\
->n=47\end{array}$ & $\begin{array}{c}46.7 \\
->n=84\end{array}$ & $\begin{array}{c}62.3 \\
->n=61\end{array}$ \\
\hline Switzerland & $\begin{array}{c}79.6 \\
->n=147 \\
\end{array}$ & $\begin{array}{c}264.4 \\
->n=147 \\
\end{array}$ & $\begin{array}{c}476.7 \\
->n=147 \\
\end{array}$ & $\begin{array}{c}157 \\
->n=10 \\
\end{array}$ & $\begin{array}{c}16 \\
->n=10 \\
\end{array}$ & $\begin{array}{c}60.9 \\
->n=137 \\
\end{array}$ & $\begin{array}{c}38.3 \\
->n=137 \\
\end{array}$ & $\begin{array}{c}87.7 \\
->147 \\
\end{array}$ & $\begin{aligned} & 51.7 \\
&-> n=147 \\
&\end{aligned}$ & $\begin{array}{c}62.6 \\
->n=147 \\
\end{array}$ & $\begin{array}{c}7.5 \\
->n=147 \\
\end{array}$ & - & - \\
\hline North America & $\begin{array}{c}78 \\
->n=21\end{array}$ & $\begin{array}{c}256.9 \\
->n=21\end{array}$ & $\begin{array}{c}>401 \\
->n=21\end{array}$ & $\begin{array}{c}159.6 \\
->n=21\end{array}$ & $\begin{array}{c}85.7 \\
->n=21\end{array}$ & $\begin{array}{c}82.6 \\
->n=21\end{array}$ & $\begin{array}{c}64.8 \\
->n=21\end{array}$ & $\begin{array}{c}100 \\
->n=21\end{array}$ & $\begin{array}{c}78.3 \\
->n=21\end{array}$ & $\begin{array}{c}34.8 \\
->n=21\end{array}$ & $\begin{aligned} & 8.7 \\
-> & n=21\end{aligned}$ & $\begin{array}{c}61 \\
\text { (systematic } \\
\text { use) } \\
->n=21\end{array}$ & - \\
\hline Germany & $\begin{array}{c}86.2 \\
->n=333\end{array}$ & $\begin{array}{c}173 \\
->n=464\end{array}$ & $\begin{array}{c}470 \\
->n=464\end{array}$ & - & - & $\begin{array}{c}86 \\
->n=287\end{array}$ & $\begin{array}{c}52 \\
->n=287\end{array}$ & 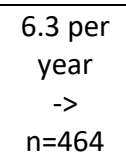 & $\begin{array}{c}1.2 \text { per year } \\
->n=464\end{array}$ & $\begin{array}{c}40.3 \\
->n=464\end{array}$ & $\begin{array}{c}0.4 \\
->n=464\end{array}$ & $\begin{array}{c}73 \\
->287\end{array}$ & - \\
\hline South America & $\begin{array}{c}90.5 \\
->n=120\end{array}$ & - & $\begin{array}{c}362 \\
->n=104\end{array}$ & - & $\begin{aligned} & <50 \\
-> & n=120\end{aligned}$ & $\begin{array}{c}100 \\
->n=104\end{array}$ & $\begin{array}{c}14.4 \\
->n=104\end{array}$ & $\begin{array}{c}91 \\
-> \\
n=104\end{array}$ & $\begin{array}{c}15 \\
->n=104\end{array}$ & $\begin{array}{c}66.3 \\
->n=104\end{array}$ & $\begin{array}{c}5.8 \\
->n=104\end{array}$ & $\begin{array}{c}88.8 \\
->n=120\end{array}$ & $\begin{array}{c}66.7 \\
->n=72\end{array}$ \\
\hline
\end{tabular}

$\rightarrow \mathrm{n}=$ total number of implanted individuals with available information for each area 
Table 3 - Implantation procedure and reliability axis (geographic areas)

\begin{tabular}{|c|c|c|c|c|c|}
\hline Author & $\begin{array}{l}\text { Deafferentation and } \\
\text { Implantation procedure }\end{array}$ & Complications following surgery & Implant failures & Impact on patients everyday life and long term side effects & Additional information \\
\hline $\begin{array}{l}\text { Austria } \\
\rightarrow \mathrm{N}=30\end{array}$ & $\begin{array}{l}\text { SARS implantation and } \\
\text { deafferentation of roots for } \\
\text { whom anterior component } \\
\text { induced detrusor } \\
\text { contractions - first patients } \\
\text { - then extension to all sacral } \\
\text { posterior roots. } \\
26 \text { intradural implant and } 4 \\
\text { extradural implantation }\end{array}$ & $\begin{array}{l}\text { - Second deafferentation }(n=5) \text {-> } \\
\text { successful procedure for } 4 \text { of them }\end{array}$ & - & $\begin{array}{l}\text { - Suspicion of Wallerian degeneration in one patient for } \\
\text { whom electromicturition was impossible at the time of the } \\
\text { study }\end{array}$ & $\begin{array}{l}\text { - Severe autonomic dysreflexia } \\
\text { disappeared in on patient } \\
\text { - Statement claiming that SARS } \\
\text { procedure improved all patients } \\
\text { Quality of life as well as no } \\
\text { patient has regretted the } \\
\text { operation }\end{array}$ \\
\hline $\begin{array}{l}\text { United Kingdom } \\
->N=24\end{array}$ & $\begin{array}{l}\text { Intradural implantation in all } \\
\text { cases with or without S2-S4 } \\
\text { rhizotomy - e.g. } 9 \\
\text { implantation with and } 3 \\
\text { without deafferentation in } \\
\text { Sheffield group }(n=12)\end{array}$ & $\begin{array}{l}\text { - Suspicion of anterior roots damage }(n=2) \\
\text { - Cerebrospinal fluid leakage }(n=2)\end{array}$ & - & $\begin{array}{l}\text { - Patient with pelvic pain awaiting for rhizotomy }(n=1) \\
\text { - Somatic muscle spasms ( } n=1 \text {, preventing implant-driven } \\
\text { micturition) } \\
\text { - Muscle spasms when using SARS implant for erection ( } n=6 \text { - } \\
\text { > never used for sexual purposes) } \\
\text { - Sphincterotomy proposed ( } n=4 \text {-> two refused and did not } \\
\text { use the implant) } \\
\text { - Hydronephrosis pre-implantation }(n=4) \text { : } \\
\text { * Resolved in two cases } \\
\text { * One patient relapsed } \\
\text { * Grade IV reflux with urgent sphincterotomy in one patients } \\
\text { - Spine fractures due to the laminectomy leaded to } \\
\text { intractable spasms and cessation of implant use }(n=1) \\
\text { - Infection leading to complete removal of the device } 2 \text { years } \\
\text { after implantation }(n=1)\end{array}$ & $\begin{array}{l}\text { - No constipation and reduced } \\
\text { time for bowel evacuation } \\
\text { reported by the Sheffield group }\end{array}$ \\
\hline $\begin{array}{l}\begin{array}{l}\text { France } \\
->N=116\end{array}\end{array}$ & $\begin{array}{l}\text { - Intradural rhizotomy and } \\
\text { implantation }(n=103)- \\
\text { Intradural rhizotomy and } \\
\text { extradural implantation } \\
(n=13)\end{array}$ & $\begin{array}{l}\text { - Cerebrospinal fluid leakage }(n=6) \\
\text { - Nearly complete denervation ( } n=5 \text {, } \\
\text { intradural implantation, stimulato could } \\
\text { be use after recovery in } 3 \text { patients) } \\
\text { - Neuropraxia }(n=1) \\
\text { - Recovery after few months }(n=1) \\
\text { - Partial denervation ( } n=5, \text { with good } \\
\text { results few months post-implantation) } \\
\text { - Second deafferentation ( } n=4 \text { ) } \\
\text { - Discomfort at the subcutaneous receptor } \\
\text { (subsequently displaced, } n=2 \text { ) }\end{array}$ & $\begin{array}{l}\text { - Extradural implantation due } \\
\text { to intradural electrode failure } \\
(n=1) \\
\text { - Replacement of receiver } \\
\text { block }(n=6) \\
\text { - Cable failures }(n=4) \\
\text { - Cable disconnection }(n=4) \\
\text { - Charger failure }(n=3)\end{array}$ & $\begin{array}{l}\text { - Transitory spasticity was mentioned but not quantitatively } \\
\text { documented. } \\
\text { - Infection leading to implant removal }(n=2) \\
\text { - Deterioration of detrusor responses }(n=5) \\
\text { - Bladder fibrosis }(n=1) \\
\text { - Persistent sphincter dyssynergia }(n=3 \text {, patient refused } \\
\text { sphincterotomy or conus deafferentation) } \\
\text { - Persistent Wallerian degeneration }(n=1) \\
\text { - Second sphincterotomy ( } n=4 \text {, all continent) } \\
\text { - Pyelonephritis ( } n=1) \\
\text { - Renal problems leaded to nephrotomy ( } n=1)\end{array}$ & $\begin{array}{l}\text { Benefit: } \\
\text { - Preoperative vesicoureteral } \\
\text { reflux disappeared }(n=3)\end{array}$ \\
\hline $\begin{array}{l}\text { Spain } \\
\rightarrow \mathrm{N}=7\end{array}$ & $\begin{array}{l}\text { Extradural implantation and } \\
\text { deafferentation at the conus } \\
\text { medullaris in all patients }\end{array}$ & $\begin{array}{l}\text { The receiver block was placed too low in } \\
\text { patient abdominal wall and broke through } \\
\text { the } s k i n(n=1)->\text { It was replaced higher up }\end{array}$ & - & - & $\begin{array}{l}\text { Benefit: } \\
\text { - Upper urinary tract dilatation } \\
\text { improved in one patient }\end{array}$ \\
\hline
\end{tabular}




\begin{tabular}{|c|c|c|c|c|c|}
\hline $\begin{array}{l}\text { Netherlands } \\
->\mathrm{N}=84\end{array}$ & $\begin{array}{l}\text { Intradural sacral posterior } \\
\text { rhizotomy (S2-S5) and } \\
\text { intradural SARS implantation } \\
\text { in all patients }\end{array}$ & $\begin{array}{l}\text { - Second deafferentation }(n=3) \\
\text { - Neuropraxie }(n=1) \\
\text { - Cerebrospinal fluid leakage }(n=3) \\
\text { - Wound infection }(n=1) \\
\text { - Nerve damage }(n=2) \\
* 1 \text { permanent } \\
\text { * } 1 \text { recovered } \\
\text { - Detrusor weakness }(n=4) \text {-> Problems } \\
\text { solved several years after surgery }\end{array}$ & $\begin{array}{l}\text { - External equipment }(n=23 \text { in } \\
\text { total) } \\
{ }^{*} \text { Cable fracture }(n=16) \\
\text { * Transmitter defects }(n=7) \\
\text { - Internal equipment }(n=4 \text { in } \\
\text { total). } \\
* 3 \text { receiver replacements }\end{array}$ & $\begin{array}{l}\text { - Strong lower limbs contractions during stimulation-induced } \\
\text { erection ( } n=12) \\
\text { - Strong motor responses to stimulation ( } n=1) \\
\text { - Fibrosis around sacral roots }(n=2) \\
\text { - Root failures }(n=1 \text {, but deafferentation enable complete } \\
\text { continence) } \\
\text { - Detrusor weakness }(n=2) \\
\text { - Sphincter weakness }(n=1) \\
\text { - Implant infection }(n=1) \text { - Replacement of the intradural } \\
\text { implant by an extradural one } \\
\text { - AHR induced by stimulation }(n=2) \\
\text { - Intrathecal baclofen pump }(n=2)\end{array}$ & $\begin{array}{l}\text { - Stimulation-induced erections } \\
\text { not used for sexual intercourse } \\
\text { - Upper urinary tract dilatation } \\
\text { solved in } 2 \text { patients } \\
\text { - Creatinine clearance returned } \\
\text { to normal values after } \\
\text { implantation ( } n=32 \text { ) } \\
\text { - Preoperative vesicoureteral } \\
\text { reflux was reduced }(n=1) \text { or } \\
\text { disappeared }(n=1) \\
\text { - No interference between SARS } \\
\text { and baclofen pump }\end{array}$ \\
\hline $\begin{array}{l}\text { Switzerland } \\
->\mathrm{N}=147\end{array}$ & $\begin{array}{l}\text { Intradural implantation and } \\
\text { deafferentation S2 to S5 in } \\
\text { all cases }\end{array}$ & $\begin{array}{l}\text { - Incomplete rhizotomy }(n=8) \text { with second } \\
\text { deafferentation }(n=4) \\
\text { - Cerebrospinal fluid leakage }(n=8) \\
\text { - Infection }(n=3)\end{array}$ & $\begin{array}{l}\text { - Defect of cables }(n=19) \\
\text { - Defect of stimulation plate } \\
\text { ( } n=19) \\
\text { - Dislocation of the stimulator } \\
\text { plate }(n=16) \\
\text { - Undetermined cause of } \\
\text { stimulator failure }(n=15)\end{array}$ & $\begin{array}{l}\text { - Additional urological interventions in } 43 \text { patients } \\
* 22 \text { Outlet obstruction } \\
* 10 \text { Vesicoureteral reflux } \\
* 10 \text { Incontinence } \\
* 9 \text { Urethral strictures } \\
\text { - Problems with condom fixation }(n=3) \\
\text { - AHR persisted and occurred during implant-driven voiding } \\
\text { despite complete sacral deafferentation }(n=8)\end{array}$ & $\begin{array}{l}\text { - In } 54 \text { patients, a total of } 83 \\
\text { surgical revisions were } \\
\text { performed ( } 17 \text { patients } \\
\text { underwent more than one } \\
\text { revision) }\end{array}$ \\
\hline $\begin{array}{l}\text { North America } \\
\rightarrow \mathrm{N}=21\end{array}$ & $\begin{array}{l}\text { Extradural implantation and } \\
\text { intradural rhizotomy S2-S5 } \\
\text { in all cases }\end{array}$ & $\begin{array}{l}\text { - Temporary nerve damage ( } n=2 \text {, recovery } \\
\text { within } 3 \text { months) } \\
\text { - Incomplete rhizotomy with second } \\
\text { deafferentation }(n=1)\end{array}$ & & $\begin{array}{l}\text { - Increased lower limb spasticity }(n=2) \\
\text { - Infection leading to complete removal of the device } 26 \\
\text { years after implantation }(n=1) \\
\text { - Increase in incontinence episodes }(n=4) \\
\text { - Fracture of the second lumbar vertebra } 5 \text { months after } \\
\text { surgery which caused compression of the cauda equina }(n=1)\end{array}$ & $\begin{array}{l}\text { Benefit: } \\
\text { - Reduced time for bowel } \\
\text { evacuation }\end{array}$ \\
\hline $\begin{array}{l}\text { Germany } \\
->N=440\end{array}$ & $\begin{array}{l}\text { Intradural deafferentation } \\
\text { and implantation. Rhizotomy } \\
\text { performed in all surgery } \\
\text { with a success rate of } 95.2 \%\end{array}$ & $\begin{array}{l}\text { - Cerebrospinal fluid leak ( } n=6) \\
\text { - Infection of the implant }(n=5) \text { with } \\
\text { further reimplantation in } 4 \text { cases } \\
\text { - Dehiscent wound ( } n=2) \\
\text { - Hemorrhages ( } n=2, \text { no further treatment) } \\
\text { - Second rhizotomy ( } n=8 \text { at conus terminlis } \\
\text { to interrupt dysreflexia) }\end{array}$ & $\begin{array}{l}-81 \text { Implant defects } \\
\rightarrow 44 \text { repair surgeries } \\
\text { * } 26 \text { Receiver exchange and } \\
\text { cable repair } \\
\text { *6 Cable repair alone } \\
\text { *12 Extradural implant with } 1 \\
\text { withdrawal due to an infection }\end{array}$ & $\begin{array}{l}\text { - Bladder overdistension and neurogenic failures are } \\
\text { mentioned but not quantitatively documented. }\end{array}$ & $\begin{array}{l}\text { - Bladder spasticity stopped in } \\
97 \% \text { of all cases. } \\
\text { Recovery of kidney function is } \\
\text { mentioned }\end{array}$ \\
\hline $\begin{array}{l}\text { South America } \\
->\mathrm{N}=120\end{array}$ & $\begin{array}{l}\text { Extradural implantation and } \\
\text { posterior rhizotomy of S2-S5 } \\
\text { sacral roots }(n=104) \text { or } S 2-S 4 \\
\text { roots }(n=16)\end{array}$ & $\begin{array}{l}\text { - Neuropraxia with spontaneous resolution } \\
\text { after } 12 \text { months }(n=2)\end{array}$ & $\begin{array}{l}\text { - Failure of the receiver block } \\
(\mathrm{n}=1) \\
\text { - Malfunction/damage of the } \\
\text { external hardware mostly due } \\
\text { to operator misuse }(n=10)\end{array}$ & $\begin{array}{l}\text { - Infections few months after implantation }(n=2) \\
\text { - Cable extrusion }(n=2) \\
\text { - Extrusion of the receiver block }(n=4)\end{array}$ & $\begin{array}{l}\text { - Stimulation-induced erections } \\
\text { rarely used for sexual } \\
\text { intercourse }\end{array}$ \\
\hline
\end{tabular}


Table 4 - Patient's quality of life

\begin{tabular}{|c|c|c|c|}
\hline Author & Population & Survey modalities & Results \\
\hline Wielink et al, 1997 & $\begin{array}{l}52 \text { implanted patients. } \\
\text { Questionnaires } \\
\text { completed at } \\
\text { baseline, } 3 \text { months, } 6 \\
\text { months and } 1 \text { year } \\
\text { follow-up }\end{array}$ & $\begin{array}{l}\text { Final survey designed by } \\
\text { using } 4 \text { indicators } \\
\text { - the Nottingham Health } \\
\text { Profile } \\
\text { - the Karnofsky } \\
\text { Performance Index } \\
\text { - the Affect Balance } \\
\text { Scale } \\
\text { - Self-developed items } \\
\text { + Cost effectiveness } \\
\text { study }\end{array}$ & $\begin{array}{l}\text { Quality of life: } \\
\text { - The Nottingham Health Profile covers several aspects such as "energy", "sleep", "emotional reaction" and "social isolation". It did } \\
\text { not show significant improvement after implantation. } \\
\text { - The Karnofsky Performance Index, initially designed in cancer research to quantify "objective" quality of life aspects, did not show } \\
\text { significant improvement after implantation. } \\
\text { - The Affect Balance Scale assessing experienced well-being improved significantly after SARS implantation. } \\
\text { - Before implantation patients showed problems with bladder emptying and incontinence especially during everyday life tasks. } \\
\text { Cost-effectiveness: } \\
\text { - Costs of treatment with SARS are high in the first } 2.5 \text { years (implantation surgery and stay in hospital) } \\
\text { - These SARS costs are earned back after } 8 \text { years compared to conventional treatment costs. } \\
\text { - The saving of money increases with the long term effects }\end{array}$ \\
\hline Creasey et al, 2001 & $\begin{array}{l}18 \text { implanted patients } \\
\text { whose completed a 6- } \\
\text { month follow-up }\end{array}$ & $\begin{array}{l}\text { User satisfaction survey } \\
\text { designed by the authors }\end{array}$ & 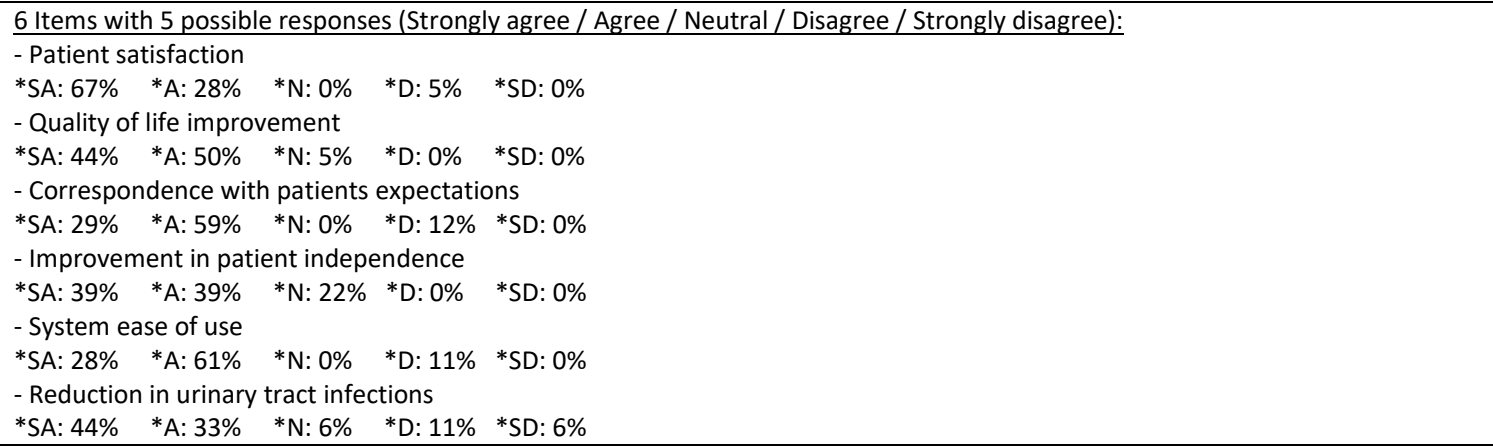 \\
\hline $\begin{array}{l}\text { Vastenholt et al, } \\
2003\end{array}$ & $\begin{array}{l}\text { Comparison between } \\
\text { two populations: } \\
\text { - } 37 \text { implanted } \\
\text { patients with a } 7 \text { years } \\
\text { follow-up period } \\
\text { - } 400 \mathrm{SCl} \text { patients } \\
\text { whose results are } \\
\text { reported in the } \\
\text { manual of the } \\
\text { Qualiveen } \\
\text { questionnaire }\end{array}$ & $\begin{array}{l}\text { Use of the Qualiveen } \\
\text { questionnaire which is a } \\
\text { disease specific } \\
\text { questionnaire } \\
\text { composed of two parts: } \\
\text { - Impact of urinary } \\
\text { problems } \\
\text { - Quality of life of } \mathrm{SCl} \\
\text { patients } \\
\text { + Patient expectations }\end{array}$ & $\begin{array}{l}\text { Qualiveen results: } \\
\text { - Impact of urinary problems on patients quality of life is smaller in the implanted patients group compared to the control group. } \\
\text { - The overall quality of life is higher in implanted patients versus control patients } \\
\text { Patient's experiences and expectations: } \\
\text { - Patients expectations with respect to micturition: } \\
\text { *Expectations met: } 62 \% \text { *Partially met: } 32 \% \\
\text { - Concerning defecation: } \\
\text { *Expectations met: } 38 \% \text { *Partially met: } 30 \% \\
\text { - Use of SARS for erection in male patients: } \\
\text { *Expectations met: } 47 \% \\
\text { Almost } 90 \% \text { patient would chose again for surgery and would recommend implantation }\end{array}$ \\
\hline Martens et al, 2011 & $\begin{array}{l}\text { Comparison between } \\
3 \text { populations: } \\
\text { - Brindley group } \\
(\mathrm{n}=46)\end{array}$ & $\begin{array}{l}\text { Survey designed with } 3 \\
\text { components: } \\
\text { - the Qualiveen } \\
\text { questionnaire }\end{array}$ & $\begin{array}{l}\text { Qualiveen questionnaire } \\
\text { - Impact of urinary problems: } \\
\text { * Patients who used SARS mentioned less limitations, constraints, fears and bad feelings concerning their urinary problems. } \\
\text { - Overall quality of life: }\end{array}$ \\
\hline
\end{tabular}




\begin{tabular}{|c|c|c|c|}
\hline & $\begin{array}{l}\text { - Rhizotomy group } \\
\text { (Brindley procedure } \\
\text { without use of the } \\
\text { implant }-n=27) \\
\text { - Control group }(n=28)\end{array}$ & $\begin{array}{l}\text { - the SF- } 36 \text { which } \\
\text { mesures the general } \\
\text { health } \\
\text { - Questions regarding } \\
\text { urinary tract infections } \\
\text { and continence }\end{array}$ & 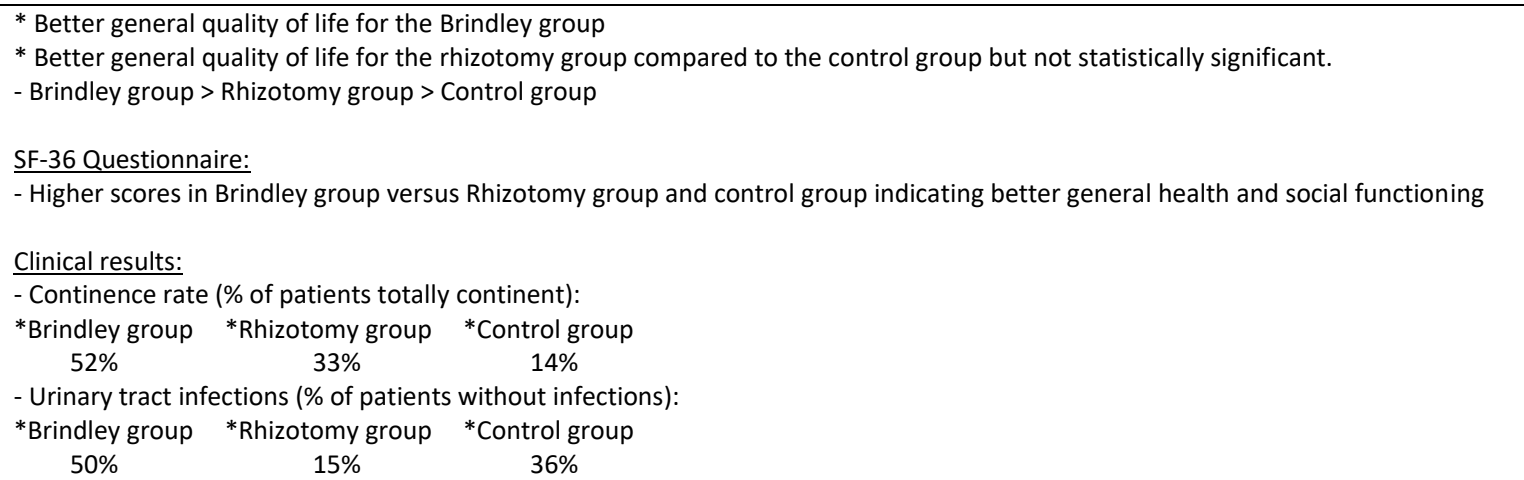 \\
\hline $\begin{array}{l}\text { Rasmussen et al, } \\
2015 \text { and Zaer et al, } \\
2018\end{array}$ & $\begin{array}{l}587 \text { implanted } \\
\text { patients. } \\
\text { Questionnaires } \\
\text { completed by } 333 \\
\text { patients and only } \\
\text { responses from those } \\
\text { who are using the } \\
\text { SARS for bowel } \\
\text { function were } \\
\text { analyzed in } \\
\text { Rasmussen et al } \\
\text { ( } n=277-145 \text { males } \\
\text { and } 132 \text { females) } \\
\text { while only those using } \\
\text { the SARS for bladder } \\
\text { function were } \\
\text { analyzed in Zaer et al } \\
\text { ( } n=287-154 \text { males } \\
\text { and } 133 \text { females). }\end{array}$ & $\begin{array}{l}\text { Combination of data } \\
\text { from both showed } \\
\text { results from } 7 \text { indicators } \\
-1 \text { for overall } \\
\text { satisfaction: Visual } \\
\text { analog scale (VAS), } \\
-1 \text { for bladder function: } \\
\text { VAS } \\
-1 \text { for sexual function: } \\
\text { VAS ( } n=284-154 \text { males } \\
\text { and } 130 \text { females) } \\
-4 \text { assessing bowel } \\
\text { function: VAS for overall } \\
\text { severity of bowel } \\
\text { symptoms; Neurogenic } \\
\text { bowel dysfunction } \\
\text { score; St Marks } \\
\text { incontinence score and } \\
\text { Cleveland constipation } \\
\text { score }\end{array}$ & $\begin{array}{l}\text { Overall satisfaction: } \\
\text { - VAS ranged from } 0 \text { (worst) to } 10 \text { (best). For the subject that are still using their implant, the median VAS score was } 10 \text { (range: } 0-10 \text { ). } \\
\text { Bladder function (for individuals using their implant): } \\
\text { - VAS ranged from } 0 \text { (minor) to } 10 \text { (major nuisance). VAS score dropped from } 9 \text { (range: } 7-10 \text { ) at baseline to } 3 \text { (1-5) at follow up. } \\
\text { Sexual function (for individuals using their implant): } \\
\text {-VAS ranged from } 0 \text { (no satisfaction) to } 10 \text { (no problems). } \\
\text { Males: No statistical difference between before and after ( } 0.41 \text { versus } 0.47 \text { ) even if males ability of performing intercourse } \\
\text { decreased. } \\
\text { Females: slightly decrease from } 6 \text { (range: } 0-10 \text { ) to } 5 \text { (0-10) without reaching statistical significance. In the same way, no statistical } \\
\text { difference between before and after regarding capability of orgasm, usage of sexual aids or medicine and ability of having sexual } \\
\text { intercourse. } \\
\text { Bowel symptoms (for individuals using their implant): } \\
\text {-VAS for overall severity of bowel symptoms, range } 0 \text { (worst) to } 10 \text { (best), was } 6 \text { (range: } 4-8 \text { ) before implantation and } 4 \text { (2-6) at follow } \\
\text { up. } \\
\text { - Neurogenic bowel dysfunction score (0-6 very minor, } 7-9 \text { minor, } 10-13 \text { moderate, } 14+\text { severe dysfunction) was } 17 \text { (range: } 11-21 \text { ) } \\
\text { before SARS procedure and } 11 \text { ( } 9-15 \text { ) at follow-up. } \\
- \text { St Marks incontinence score (0=perfect continence, } 24=\text { totally incontinence) remains } 4 \text { before and after implantation (range: } 0-7 \\
\text { and } 0-5 \text { respectively). } \\
\text { - Cleveland constipation score ( } 0=\text { minimal, } 30=\text { worst constipation) slightly decrease from } 7 \text { (range: } 6-10 \text { ) at baseline to } 6 \text { (4-8) at } \\
\text { follow-up. }\end{array}$ \\
\hline
\end{tabular}




\section{Table 5 - Additional information}

\begin{tabular}{|c|c|c|}
\hline Author & Deafferentation & General description \\
\hline Kirkham et al, 2002 & $\begin{array}{l}\text { - Extradural }(80 \%) \text { or } \\
\text { intradural }(20 \%) \\
\text { implantation of SARS } \\
\text { - No rhizotomy }\end{array}$ & $\begin{array}{l}\text { Implantation of SARS implant on both anterior and posterior roots for neuromodulation purposes. In all patient, stimulation increase } \\
\text { bladder capacity and reflex erection was preserved. However, micturition was only elicited in one patient - Patient for whom } \\
\text { micturition cannot be for sure imputed to implant use. }\end{array}$ \\
\hline Soni et al, 2004 & $\begin{array}{l}\text { intradural implantation } \\
\text { of SARS and S2, S3 and } \\
\text { S4 posterior roots } \\
\text { rhizotomy }\end{array}$ & $\begin{array}{l}\text { A patient using SARS implant for micturition noticed progressively increasing spasms. These spasms required intrathecal baclofen } \\
\text { therapy but subsequent lumbar spine fractures }-L 4 \text { and } L 5 \text { vertebral bodies - leaded to intractable spasms and to cessation of } \\
\text { implant use. }\end{array}$ \\
\hline $\begin{array}{l}\text { Vaidyanathan et al, } \\
2009\end{array}$ & $\begin{array}{l}\text { - Intradural rhizotomy } \\
\text { and implantation }\end{array}$ & $\begin{array}{l}\text { Person with SCI with a history of bladder calculus underwent sacral deafferentation and SARS implantation. Chronic infections by } \\
\text { Pseudomonas aeruginosa led to implant removal, causing loss of bladder emptying. Deafferentation and failed implantation induced } \\
\text { severe constipation and loss of - reflex - penile erection. The long-term consequences of unsuccessful bladder stimulator surgery } \\
\text { had dramatic effects on patient quality of life. }\end{array}$ \\
\hline Pannek et al, 2010 & $\begin{array}{l}\text { Intradural rhizotomy } \\
\text { without implantation }\end{array}$ & $\begin{array}{l}\text { S2 to S5 deafferentation as a salvage procedure in a patient with life-threatening autonomic dysreflexia. This bladder-triggered } \\
\text { dysreflexia even leading to cardiac arrest, it was decided to perform sacral deafferentation to prevent further critical episodes. The } \\
\text { patient nevertheless rejected any implant and } 3 \text { month after surgery declare himself content with suprapubic catheter while no } \\
\text { episodes of autonomic dysreflexia occurred. }\end{array}$ \\
\hline Sanders et al, 2011 & $N A^{a}$ & $\begin{array}{l}\text { Patient preferences for next generation of neural prostheses. A fractional factorial study was designed to identify patient } \\
\text { preferences regarding new neuroprosthetic devices. This study aimed to identify the key features for implant attractiveness and } \\
\text { compared three stimulation modalities: Brindley implant, pudendal nerve stimulation and Brindley system without dorsal rhizotomy. } \\
\text { In a nutshell, "side effects" and invasiveness seemed to be the most important features while patient preferences established the } \\
\text { following ranking: Brindley system without dorsal rhizotomy > pudendal nerve stimulation > Brindley implant. }\end{array}$ \\
\hline De Heredia et al, 2012 & $N A^{a}$ & $\begin{array}{l}\text { Investigation of MRI exams impact on SARS implant in } 18 \text { patients. A total of } 44 \text { MRI examinations were performed, } 34 \text { at } 0.2 \text { Tesla } \\
\text { and } 21 \text { at } 1.5 \text { Tesla. } \\
\text { Side effects: Two MRI on the same patient were stopped due to interference with the SARS (toe movements at } 0.2 \text { Tesla, a } \\
\text { subsequent MRI at } 1.5 \text { Tesla was performed without complications). No other adverse effects could be directly attributed to MRI } \\
\text { exams. }\end{array}$ \\
\hline Bramall et al, 2016 & $\begin{array}{l}\text { - Intradural implantation } \\
\text { of SARS } \\
\text { - No rhizotomy }\end{array}$ & $\begin{array}{l}\text { Person with SCI remained incontinent after SARS implantation leading his physician to remove the receiver block while leaving the } \\
\text { electrodes and associated wires. Repeated skin breakdown with wired extrusion happened in subsequent patient medical history } \\
\text { ultimately leading to a chronic Staphylocccus aureus infection and sacral osteomyelitis } 26 \text { years after implantation. Definitive } \\
\text { management involved complete removal of the device and the intradural phlegmon as well as ligation of the thecal sac and flap } \\
\text { reconstruction. }\end{array}$ \\
\hline Krebs et al, 2016 & $\begin{array}{l}\text { - Intradural rhizotomy } \\
\text { and implantation }\end{array}$ & $\begin{array}{l}\text { Long-term follow up of detrusor contractions in spinal cord injured individuals implanted with sacral anterior root stimulator (mean } \\
\text { follow-up=11.7 years). Detrusor pressures induced by stimulation decreased over time without reaching statistical significance. This } \\
\text { decrease neither resulted in an increase in the number of daily stimulation-induced voiding nor in an increase in residual urine after } \\
\text { voiding. The origin of the deterioration of bladder contraction remains unknown even if neurogenic deterioration in the wake of SCI, } \\
\text { long-term SAR or aging are likely to be incriminated. }\end{array}$ \\
\hline
\end{tabular}


Guiho T, Azevedo-Coste C, Bauchet L, Delleci C, Vignes JR, Guiraud, D, Fattal C. Forty Sacral Anterior Root Stimulation and visceral function outcomes in spinal cord injury - A systematic review of the literature over four decades, World Neurosurgery, 2021.

Supplementary Fig.1 - Cochrane's Risk of Bias in Non-randomized Studies of Interventions

\begin{tabular}{|c|c|}
\hline Roonson a dat: 1988 & $\oplus \otimes$ \\
\hline Bindely ytat, 1990 & $x+\otimes \Theta \oplus \Theta \oplus \otimes$ \\
\hline MacDonagh et at. 19san & $\Theta \oplus \theta+\otimes+\otimes \odot$ \\
\hline 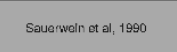 & $-6-00$ \\
\hline Barate tad. 1993 & $-\otimes \otimes-\otimes-\Theta \otimes$ \\
\hline Egon tat, 1993 & $\Theta \otimes \Theta \Theta \otimes+\oplus \otimes$ \\
\hline Madersbachere of al, 1993 & 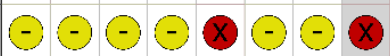 \\
\hline Saraias ciat, 1999 & $\otimes \otimes-\theta 0-\otimes \otimes$ \\
\hline Bimerer,1994 & $\Theta \oplus \Theta \Theta \oplus+\oplus \oplus$ \\
\hline Berideter. 1995 & $\Theta \oplus \Theta \odot \oplus+\oplus \oplus$ \\
\hline Van heraemacke tat, 1996 & $\oplus \theta \oplus \theta+\oplus+\oplus$ \\
\hline 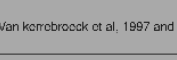 & $\oplus \oplus \oplus \Theta \oplus+\oplus \oplus$ \\
\hline Welinket at, 1997 & $\oplus \oplus \oplus \Theta \oplus \oplus \oplus \oplus$ \\
\hline Egane tal tal 1988 & $\oplus \oplus \oplus \odot \oplus \oplus \oplus \oplus$ \\
\hline scturch tat, 1998 & $\Theta \Theta \oplus \oplus \Theta \oplus \Theta \Theta$ \\
\hline Van cer An e tal. 1999 & $\Theta \oplus \oplus \otimes \Theta \oplus \oplus \Theta$ \\
\hline Bustertet at: 2001 & $\Theta \oplus+\oplus \oplus+\oplus \oplus$ \\
\hline 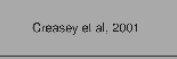 & $\Delta \oplus \oplus+\oplus \oplus \oplus \oplus$ \\
\hline Keirtanam atal, 2002 & $\theta \oplus \theta \oplus \oplus \oplus \oplus \otimes$ \\
\hline Sauemente tat 2003 & $\theta-\theta \Theta \otimes-\infty \otimes$ \\
\hline 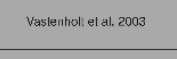 & $\oplus+\oplus \odot \oplus \oplus \oplus \oplus$ \\
\hline Hanal at a, 2009 & 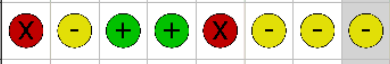 \\
\hline Sonic at. 2004 & $\otimes \otimes \otimes 0 \otimes-\theta \otimes$ \\
\hline Kuzzentererge et at. 2005 & $\oplus \oplus \oplus \oplus \Theta \Theta \Theta \Theta$ \\
\hline 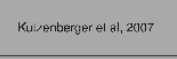 & $\oplus \oplus \oplus \oplus \odot \odot \odot \odot$ \\
\hline Valty,ganathan en at, 2009 & 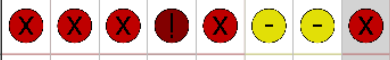 \\
\hline Panneke tat 2010 & 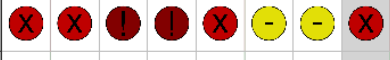 \\
\hline Materens at a, 2011 & $\oplus+\oplus \oplus \oplus \oplus \oplus \oplus$ \\
\hline Sardestes etat 2011 & $0 \oplus 0 \oplus \oplus \oplus \otimes-$ \\
\hline Do Horedala a tal. 2012 & $\oplus+\otimes \otimes \odot \oplus \Theta \Theta$ \\
\hline Krasniketat, 2014 & $\oplus \oplus \oplus \oplus-\oplus \oplus \oplus$ \\
\hline Baranaletetic 2016 & $\otimes \otimes \otimes 0 \otimes 00 \otimes$ \\
\hline 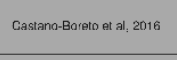 & $\theta \oplus \oplus \oplus-\oplus \oplus \oplus$ \\
\hline Krebs otal, 2016 & $\oplus+\oplus \oplus+\oplus \Theta \oplus$ \\
\hline Rasmussen tat. 2015 & $\oplus+\oplus \oplus \otimes+\oplus \oplus$ \\
\hline Zaet el al: 2018 & $\oplus \oplus \oplus \oplus \otimes+\oplus \oplus$ \\
\hline Fanase a a a , 2020 & 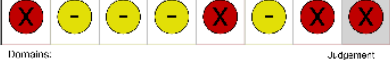 \\
\hline & 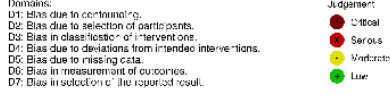 \\
\hline
\end{tabular}

(ROBINS-I) plot

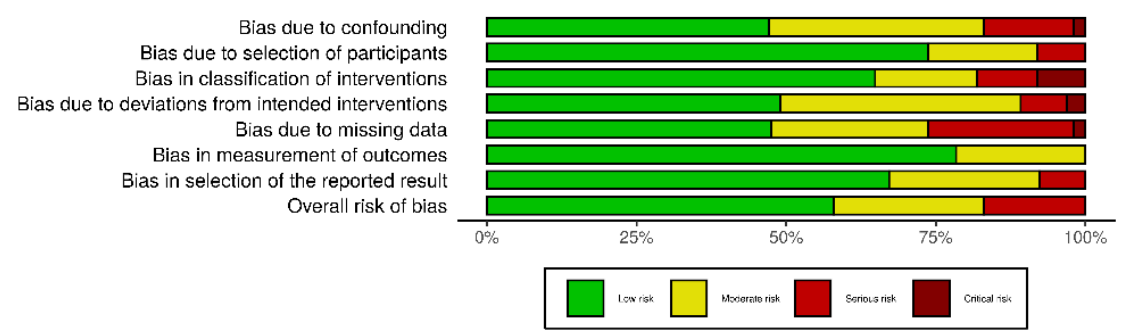


Guiho T, Azevedo-Coste C, Bauchet L, Delleci C, Vignes JR, Guiraud, D, Fattal C. Forty Sacral Anterior Root Stimulation and visceral function outcomes in spinal cord injury - A systematic review of the literature over four decades, World Neurosurgery, 2021.

Supplementary Fig.2 - Articles characteristics. a) Distribution of the selected publications classified according to their topics and their year of publication, b) Strength of evidence of the selected articles

Articles dedicated to Brindley implant

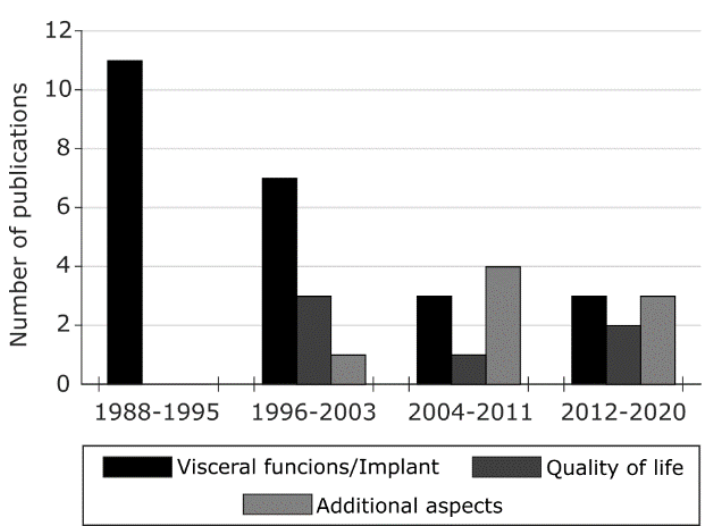

Strength of evidence

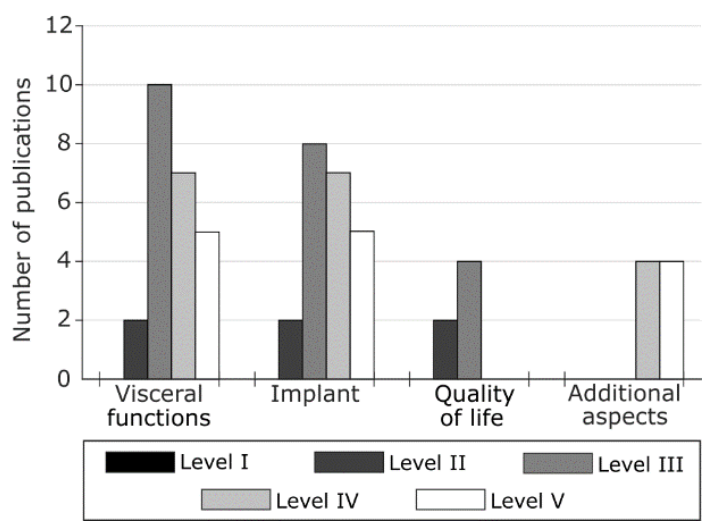


Guiho T, Azevedo-Coste C, Bauchet L, Delleci C, Vignes JR, Guiraud, D, Fattal C. Forty Sacral Anterior Root Stimulation and visceral function outcomes in spinal cord injury - A systematic review of the literature over four decades, World Neurosurgery, 2021.

\section{Supplementary Tab.1 - Study and patient characteristics (all studies)}

\begin{tabular}{|c|c|c|c|c|c|c|c|c|}
\hline Authors & $\begin{array}{c}\text { Number of } \\
\text { patients / \% of } \\
\text { male patient }\end{array}$ & Mean age in years $\left({ }^{*}\right)$ & $\begin{array}{l}\text { Lesion profile } \\
\text { T- Tetraplegia } \\
\text { P- Paraplegia }\end{array}$ & $\begin{array}{c}\text { \% of complete } \\
\text { SCI }\end{array}$ & $\begin{array}{l}\text { Mean age of the lesion } \\
\text { at the time of } \\
\text { implantation } \\
\text { (in years) }\end{array}$ & $\begin{array}{l}\text { Patients follow up } \\
\text { after implantation } \\
\quad \text { (in years) }\end{array}$ & Study type & Level of evidence \\
\hline $\begin{array}{c}\text { Madersbacher et al, } \\
1988\end{array}$ & $7 / 14$ & $\begin{array}{c}26.3 \\
{[17-45]}\end{array}$ & $\begin{array}{l}\text { Trauma: } 7 \\
\mathrm{~T}-3 / \mathrm{P}-4 \\
\end{array}$ & 86 & $\begin{array}{l}1.86 \\
{[1-3]} \\
\end{array}$ & $\begin{array}{c}- \\
{[0.5-2]}\end{array}$ & RS & IV \\
\hline Robinson et al, 1988 & $22 / 91$ & - & $\begin{array}{l}\text { Trauma: } 22 \\
\mathrm{~T}-7 / \mathrm{P}-15 \\
\end{array}$ & 91 & $\begin{array}{c}4.5 \\
{[1-22]} \\
\end{array}$ & - & RS & IV \\
\hline Brindley et al, 1990 & $50 / 76$ & $\begin{array}{c}32.08 \\
{[57-19]^{\mathrm{a}}}\end{array}$ & $\begin{array}{c}\text { Trauma: } 48 \\
\mathrm{~T}-10 / \mathrm{P}-38 \\
\text { MS: } 2 \\
\end{array}$ & 77.08 & - & $\stackrel{-}{[5-11]}$ & RS & IV \\
\hline MacDonagh et al, 1990 & $12 / 75$ & - & $\begin{array}{l}\text { Trauma: } 12 \\
\mathrm{~T}-2 / \mathrm{P}-10\end{array}$ & 100 & $>2$ & $\begin{array}{c}2.2 \\
{[0.25-6]} \\
\end{array}$ & PS & III \\
\hline Sauerwein et al, 1990 & $12 / 50$ & $\begin{array}{c}36 \\
{[24-52]^{\mathrm{a}}}\end{array}$ & $\begin{array}{c}\text { Trauma: } 12 \\
\mathrm{~T}-1 / \mathrm{P}-11\end{array}$ & 83.3 & $\begin{array}{c}9 \\
{[1-27]} \\
\end{array}$ & $\begin{array}{c}1.31 \\
{[2.5-0.08]} \\
\end{array}$ & RS & IV \\
\hline Barat et al, 1993 & $9 /-$ & - & - & - & - & - & $\mathrm{RS}-\mathrm{SC}$ & $\mathrm{V}$ \\
\hline Egon et al, 1993 & $30 / 70$ & - & - & - & - & - & $\mathrm{RS}-\mathrm{SC}$ & $\mathrm{V}$ \\
\hline $\begin{array}{c}\text { Madersbacher et al, } \\
1993 \\
\end{array}$ & $30 / 27$ & - & $\begin{array}{c}\text { Trauma: } 30 \\
\mathrm{~T}-10 / \mathrm{P}-20\end{array}$ & 97 & - & $<8$ & RS & $\mathrm{v}$ \\
\hline Sarrias et al, 1993 & $7 / 14.3$ & - & $\begin{array}{c}\text { Trauma: } 7 \\
\mathrm{~T}-3 / \mathrm{P}-4 \\
\end{array}$ & - & - & - & $\mathrm{RS}-\mathrm{SC}$ & $\mathrm{v}$ \\
\hline $\begin{array}{c}\text { Brindley, } 1994 \text { and } \\
\text { Brindley, } 1995\end{array}$ & $500 / 54.2$ & - & $\begin{array}{c}\text { Trauma: } 378 \\
T-122 \text { / P }-256 \\
\text { Unspecified : } 98 \\
\end{array}$ & 85.5 & - & $\begin{array}{c}4.07 \\
{[0.25-16.1]} \\
\end{array}$ & RS & III \\
\hline $\begin{array}{c}\text { Van kerrebroeck et al, } \\
1996\end{array}$ & $52 / 55.8$ & $\begin{array}{c}32.9 \\
{[16-57]^{\mathrm{a}}}\end{array}$ & $\begin{array}{c}\text { Trauma: } 52 \\
T-11 / P-41 \\
\end{array}$ & 100 & $\begin{array}{c}6.25 \\
{[0.75-22.5]} \\
\end{array}$ & $\begin{array}{c}3.2 \\
{[0.25-6.33]} \\
\end{array}$ & RS & IV \\
\hline $\begin{array}{c}\text { Van kerrebroeck et al, } \\
1997 \text { and } \\
\text { Wielink et al, } 1997 \\
\end{array}$ & $52 / 78.85$ & $\begin{array}{c}28.5 \\
{[16-54]^{\mathrm{ab}}}\end{array}$ & $\begin{array}{l}\text { Trauma: } 52 \\
T-11 / \mathrm{P}-41\end{array}$ & 100 & $\begin{array}{c}6.4 \\
{[0.75-24.8]}\end{array}$ & 1.14 & PS & III \\
\hline Egon et al, 1998 & $96 / 73.1$ & $\begin{array}{c}38.9 \\
{[23-66]^{\mathrm{a}}}\end{array}$ & $\begin{array}{c}\text { Trauma: } 96 \\
\mathrm{~T}-41 / \mathrm{P}-55\end{array}$ & 82.3 & $\begin{array}{c}6.67 \\
{[1-21]} \\
\end{array}$ & $\begin{array}{c}5.52 \\
{[0.5-14]} \\
\end{array}$ & RS & IV \\
\hline Schurch et al, 1998 & $10 / 30$ & $\begin{array}{c}28.7 \\
{[18-42]^{\mathrm{a}}}\end{array}$ & $\begin{array}{l}\text { Trauma: } 10 \\
\mathrm{~T}-5 / \mathrm{P}-5\end{array}$ & 90 & $\begin{array}{c}5.23 \\
{[1.2-16.7]} \\
\end{array}$ & $\begin{array}{c}3.8 \\
{[1.92-6.03]} \\
\end{array}$ & RS & III \\
\hline Van der Aa et al, 1999 & $38 / 86.8$ & $\begin{array}{c}35.03 \\
{[18-59]^{\mathrm{a}}}\end{array}$ & $\begin{array}{c}\text { Trauma: } 38 \\
T-9 / P-29\end{array}$ & 100 & $\begin{array}{c}6.95 \\
{[1-39]} \\
\end{array}$ & $\begin{array}{c}- \\
{[0.25-12]} \\
\end{array}$ & RS & III \\
\hline Bauchet et al, 2001 & $20 / 30$ & $\begin{array}{c}34 \\
{[17-53]^{\mathrm{a}}}\end{array}$ & $\begin{array}{c}\text { Trauma: } 20 \\
\mathrm{~T}-6 / \mathrm{P}-14\end{array}$ & 100 & $\begin{array}{c}6,25 \\
{[1.25-23.83]}\end{array}$ & $\begin{array}{c}4.5 \\
{[1-8.5]}\end{array}$ & RS & III \\
\hline Creasey et al, 2001 & $23 / 70$ & $\begin{array}{c}40 \\
{[14-67]^{a}}\end{array}$ & $\begin{array}{c}\text { Trauma: } 23 \\
\text { T-6/P-17 }\end{array}$ & 100 & $\begin{array}{c}7 \\
{[2-26]} \\
\end{array}$ & $\begin{array}{l}>1 \text { year but some } \\
\text { results are missing }\end{array}$ & PS & III \\
\hline Kirkham et al, 2002 & $5 / 100$ & $\begin{array}{c}37.2 \\
{[32-46]^{\mathrm{a}}}\end{array}$ & $\begin{array}{c}\text { Trauma: } 5 \\
\text { P-5 }\end{array}$ & 100 & 8.4 & - & RA & IV \\
\hline Sauerwein et al, 2003 & $427 / 33$ & $34^{\mathrm{a}}$ & Unspecified: 427 & - & - & 6.2 & $\mathrm{RS}-\mathrm{SC}$ & $\mathrm{v}$ \\
\hline Vastenholt et al, 2003 & $37 / 86.52$ & 43 & Trauma: 47 & 100 & 7.25 & 7.1 & CSS & II \\
\hline
\end{tabular}




\begin{tabular}{|c|c|c|c|c|c|c|c|c|}
\hline & & {$[23-63]^{b}$} & $T-14 / P-23$ & & {$[0.9-39.25]$} & {$[1.3-13.25]$} & & \\
\hline Hamel et al, 2004 & $4 / 100$ & - & $\begin{array}{c}\text { Unspecified: } 4 \\
T-1 / \mathrm{P}-3\end{array}$ & 100 & - & $\begin{array}{c}- \\
{[0.5-1.75]}\end{array}$ & RS & IV \\
\hline Soni et al, 2004 & $1 / 100$ & $46^{\mathrm{a}^{\circ}}$ & - & 100 & 17 & 8 & $\mathrm{CR}$ & $\mathrm{v}$ \\
\hline Kutzenberger et al, 2005 & $464 / 31$ & - & $\begin{array}{l}\text { Unspecified: } 464 \\
P-464\end{array}$ & - & - & $\begin{array}{c}6.6 \\
{[0.5-17]}\end{array}$ & $\mathrm{RS}-\mathrm{SC}$ & IV \\
\hline Kutzenberger, 2007 & $464 / 53$ & $33[14-67]^{a}$ & $\begin{array}{c}\text { Trauma: } 436 \\
\text { Other specified causes: } \\
28 \\
T-190 / \mathrm{P}-274 \\
\end{array}$ & 75 & {$[0.5-46]$} & $\begin{array}{c}8.6 \\
{[1.5-18]}\end{array}$ & RS & IV \\
\hline $\begin{array}{c}\text { Vaidyanathan et al, } \\
2009 \\
\end{array}$ & $1 / 100$ & 23 & $\begin{array}{c}\text { Trauma: } 1 \\
\mathrm{~T}-1 \\
\end{array}$ & 100 & 3 & 13 & $C R$ & $\mathrm{v}$ \\
\hline Pannek et al, 2010 & $1 / 100$ & $53^{\circ}$ & $\begin{array}{c}\text { Trauma: } 1 \\
\mathrm{P}-1 \\
\end{array}$ & 100 & $\begin{array}{c}34 \\
\text { - rhizotomy only } \\
\end{array}$ & 0.25 & $C R$ & $\mathrm{v}$ \\
\hline \multirow{3}{*}{ Martens et al, 2011} & $\begin{array}{c}\text { Group \#1 } \\
\text {-Brindley } \\
46 / 78\end{array}$ & $\begin{array}{c}48 \\
{[33-67]^{\mathrm{b}}}\end{array}$ & Unspecified: 46 & - & 8 & $\begin{array}{c}13 \\
{[1-19]}\end{array}$ & \multirow{3}{*}{$\operatorname{css}$} & \multirow{3}{*}{ II } \\
\hline & $\begin{array}{l}\text { Group \#2 } \\
\text {-Rhizotomy } 27 / \\
81\end{array}$ & $\begin{array}{c}47 \\
{[26-66]^{b}}\end{array}$ & Unspecified: 27 & - & 5 & $\begin{array}{c}14 \\
{[3-21]}\end{array}$ & & \\
\hline & $\begin{array}{l}\text { Group } \# 3 \\
\text { - Control } \\
28 / 79 \\
\end{array}$ & $\begin{array}{c}42 \\
{[20-75]^{\mathrm{b}}}\end{array}$ & Unspecified: 28 & 100 & NA & NA & & \\
\hline Sanders et al, 2011 & $66 / 89.4$ & $\begin{array}{c}50.6 \\
(\mathrm{sd}: 1.9)^{\mathrm{b}}\end{array}$ & $\begin{array}{c}\text { Trauma: } 66 \\
T-38 / P-28\end{array}$ & 31.6 & NA & NA & RA & IV \\
\hline De Heredia et al, 2012 & $18 / 66.6$ & $\begin{array}{l}\text { First MRI: } \\
46 \\
{[24-69]}\end{array}$ & $\begin{array}{l}\text { Unspecified: } 18 \\
\mathrm{~T}-2 / \mathrm{P}-16\end{array}$ & - & $\begin{array}{c}7 \\
{[1-18]}\end{array}$ & $\begin{array}{c}0.5 \text { years after MRI } \\
\text { exam }\end{array}$ & RS & IV \\
\hline Krasmik et al, 2014 & $137 / 59.1$ & $\begin{array}{c}40 \\
\text { (sd: } 12.4)^{\mathrm{a}}\end{array}$ & $\begin{array}{l}\text { Trauma: } 137 \\
T-53 / P-84\end{array}$ & 96.35 & $\begin{array}{c}11.6 \\
\text { (sd: } 10.2)\end{array}$ & $\begin{array}{c}14.8 \\
\text { (sd: } 5.3)\end{array}$ & RS & III \\
\hline $\begin{array}{l}\text { Bramall et al, } \\
2016\end{array}$ & $1 / 100$ & 36 & $\begin{array}{c}\text { Trauma: } 1 \\
\mathrm{P}-1\end{array}$ & 100 & 14 & 26 & $C R$ & $\mathrm{v}$ \\
\hline $\begin{array}{l}\text { Castano-Boreto et al, } \\
2016\end{array}$ & $104 / 91.3$ & $\begin{array}{c}38 \\
(\mathrm{sd}: 10)^{\mathrm{a}}\end{array}$ & $\begin{array}{l}\text { Trauma: } 103 \\
\text { Unspecified: } 1 \\
\text { T-34 / P }-70\end{array}$ & 92.3 & $\begin{array}{c}6.5 \\
\text { (sd: } 4.9)\end{array}$ & - & RS & III \\
\hline $\begin{array}{c}\text { Krebs et al, } \\
2016 \\
\end{array}$ & $111 / 53$ & - & $\begin{array}{c}\text { Unspecified: } \\
\mathrm{T}-39 / \mathrm{P}-72 \\
\end{array}$ & - & 8.6 & $\begin{array}{c}11.7 \\
{[5-24.9]}\end{array}$ & RS & IV \\
\hline $\begin{array}{l}\text { Rasmussen et al, } 2015 \\
\text { and Zaer et al, } 2018\end{array}$ & $587 / 57$ & 34.9 & $\begin{array}{c}\text { Trauma: } 561 \\
\text { Other specified causes: } 26 \\
\text { T-266/ / }-321 \\
\end{array}$ & 84.5 & $\begin{array}{c}8.9 \\
{[0-49]}\end{array}$ & $\begin{array}{c}14.6 \\
{[1-25]}\end{array}$ & cSS & III \\
\hline $\begin{array}{c}\text { Ramos et al, } \\
2020\end{array}$ & $16 / 81$ & $43[31-59]^{a}$ & $\begin{array}{c}\text { Unspecified: } 16 \\
\mathrm{~T}-8 / \mathrm{P}-8\end{array}$ & - & - & 4.4 & RS-SC & $\mathrm{v}$ \\
\hline
\end{tabular}

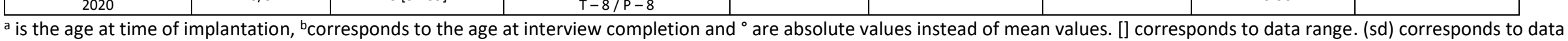
standard deviation. RS: Retrospective Study, PS: Prospective study, SC: Short Communication, CR: Case Report, CSS: Cross-sectional study, RA: Research Article. NA: Not Applicable. 
Guiho T, Azevedo-Coste C, Bauchet L, Delleci C, Vignes JR, Guiraud, D, Fattal C. Forty Sacral Anterior Root Stimulation and visceral function outcomes in spinal cord injury - A systematic review of the literature over four decades, World Neurosurgery, 2021.

Supplementary Tab.2 - Benefits for visceral functions (all studies)

\begin{tabular}{|c|c|c|c|c|c|c|c|c|c|c|c|c|c|}
\hline \multirow[t]{2}{*}{ Author } & \multirow{2}{*}{$\begin{array}{l}\text { Use of SARS for } \\
\text { micturition (\%) }\end{array}$} & \multicolumn{2}{|c|}{$\begin{array}{l}\text { Bladder capacity } \\
(\mathrm{ml})\end{array}$} & \multicolumn{2}{|c|}{$\begin{array}{l}\text { Residual urine } \\
\text { (ml) }\end{array}$} & \multicolumn{2}{|c|}{$\begin{array}{l}\text { Incontinent episodes } \\
(\%)\end{array}$} & \multicolumn{2}{|c|}{ Urinary tract infections } & \multicolumn{2}{|c|}{ Autonomic dysreflexia (\%) } & \multirow{2}{*}{$\begin{array}{c}\text { Use for } \\
\text { defecation (\%) }\end{array}$} & \multirow{2}{*}{$\begin{array}{l}\text { Use for } \\
\text { erection } \\
(\%)\end{array}$} \\
\hline & & Before & After & Before & After & Before & After & Before & After & Before & After & & \\
\hline $\begin{array}{l}\text { Madersbacher et } \\
\text { al, } 1988(n=7)\end{array}$ & 100 & $\begin{array}{c}209 \\
{[80-350]}\end{array}$ & $\begin{array}{l}350< \\
{[350-} \\
500<]\end{array}$ & $\begin{array}{c}130 \\
{[50-200]}\end{array}$ & $\begin{array}{c}27 \\
{[10-40]}\end{array}$ & - & - & - & 0 & - & - & 29 & $\begin{array}{c}100 \\
(1 / 1 \text { male) }\end{array}$ \\
\hline $\begin{array}{c}\text { Robinson et al, } \\
1988(n=22) \\
\end{array}$ & 73 & - & - & - & - & - & 32 & - & - & - & - & - & $\begin{array}{c}30 \\
\text { (6/20 males) } \\
\end{array}$ \\
\hline $\begin{array}{c}\text { Brindley et al, } \\
1990 \\
(n=48)^{\mathrm{a}} \\
\end{array}$ & 85.4 & - & - & - & - & - & $\begin{array}{c}44 \\
\text { (SARS users) }\end{array}$ & - & $\begin{array}{c}29.2 \% \\
\text { (SARS users) }\end{array}$ & - & - & 56.2 & $\begin{array}{c}43.2 \\
(16 / 37 \\
\text { males) } \\
\end{array}$ \\
\hline $\begin{array}{l}\text { MacDonagh et al, } \\
1990(\mathrm{n}=12)\end{array}$ & 100 & - & - & - & - & - & - & - & - & - & - & $\begin{array}{l}50 \text { (SARS } \\
\text { alone) }\end{array}$ & - \\
\hline $\begin{array}{c}\text { Sauerwein et al, } \\
1990(n=12)\end{array}$ & 75 & - & 565 & - & $\begin{array}{l}<50 \text { in } 75 \% \\
\text { of patients }\end{array}$ & 75 & 25 & - & - & - & - & - & - \\
\hline $\begin{array}{c}\text { Egon et al, } 1993 \\
(n=30)\end{array}$ & 90 & - & - & - & $\begin{array}{l}<50 \text { in } 83 \% \\
\text { of patients }\end{array}$ & - & - & - & - & - & - & - & - \\
\hline $\begin{array}{c}\text { Madersbacher et } \\
\text { al, } 1993(n=30)\end{array}$ & 90 & - & - & - & $<50$ & 100 & 7 & - & - & - & - & - & - \\
\hline $\begin{array}{l}\text { Sarrias et al, } 1993 \\
\qquad(\mathrm{n}=7)\end{array}$ & 100 & - & $\begin{array}{l}>400 \text { in all } \\
\text { patients }\end{array}$ & - & $\begin{array}{l}<50 \text { in all } \\
\text { patients }\end{array}$ & - & 0 & - & - & - & - & 100 & $\begin{array}{c}100 \\
(1 \text { male } \\
\text { patient })\end{array}$ \\
\hline $\begin{array}{c}\text { Brindley, 1994 } \\
\text { and Brindley, } \\
1995 \\
(n=479)^{a} \\
\end{array}$ & 86.2 & - & - & - & - & - & - & - & - & - & - & - & - \\
\hline $\begin{array}{l}\text { Van kerrebroeck } \\
\text { et al, } 1996(n=47)^{\text {a }}\end{array}$ & 87.2 & - & $\begin{array}{c}590 \text { (sd: } \\
104) \\
{[374-792]}\end{array}$ & - & $\begin{array}{l}<50 \text { in all } \\
\text { patients }\end{array}$ & - & 8.5 & $\begin{array}{l}4.2 \text { per } \\
\text { year } \\
{[2-12]}\end{array}$ & $\begin{array}{c}1.4 \text { per year } \\
{[0-2]}\end{array}$ & 15.9 & 4.25 & 36.2 & $\begin{array}{c}62(18 / 29 \\
\text { males) }\end{array}$ \\
\hline $\begin{array}{l}\text { Van kerrebroeck } \\
\text { et al, } 1997 \text { and } \\
\text { Wielink et al, } \\
1997(n=52)\end{array}$ & 100 & $\begin{array}{c}285.4 \\
{[20-780]}\end{array}$ & $\begin{array}{c}571.2 \\
{[260-806]}\end{array}$ & $\begin{array}{l}104.7 \\
{[0-600]}\end{array}$ & $\begin{array}{c}45.6 \\
{[0-600] \text { at }} \\
\text { one year } \\
(n=31)\end{array}$ & $\begin{array}{l}90 \text { (daytime) } \\
96 \text { (night) }\end{array}$ & $\begin{array}{l}21 \text { (daytime) } \\
12 \text { (night) at } \\
\text { one year }\end{array}$ & $\begin{array}{c}92 \% \\
1.94 \text { per } \\
\text { year [0- } \\
15] \\
\end{array}$ & $\begin{array}{c}27 \% \\
0.31 \text { at one } \\
\text { year [0-3] }\end{array}$ & 13.5 & 5.8 & $\begin{array}{l}\text { Clear benefit } \\
\text { mentioned for } \\
2 / 3 \text { of the } \\
\text { patients }\end{array}$ & $\begin{array}{c}78 \\
\text { (32/41 } \\
\text { males) }\end{array}$ \\
\hline $\begin{array}{l}\text { Egon et al, } 1998 \\
\quad(n=93)^{\mathrm{a}}\end{array}$ & 89.3 & 206 & 564 & - & 1 & 98.6 & 11.8 & 100 & 29 & 22.9 & 0 & 54.8 & $\begin{array}{c}70.8 \\
(46 / 65) \\
\end{array}$ \\
\hline $\begin{array}{c}\text { Schurch et al, } \\
1998(\mathrm{n}=10) \\
\end{array}$ & 100 & $\begin{array}{c}160 \\
\text { (sd: } 82)\end{array}$ & $\begin{array}{c}>500 \text { in all } \\
\text { cases }\end{array}$ & $\begin{array}{c}157 \\
\text { (sd: } 138) \\
\end{array}$ & $\begin{array}{c}16 \\
\text { (sd: } 22) \\
\end{array}$ & 100 & - & $80 \%$ & $60 \%$ & 80 & 80 & - & - \\
\hline $\begin{array}{l}\text { Van der Aa et al, } \\
1999(n=37)^{\mathrm{a}}\end{array}$ & 91.9 & $\begin{array}{c}>400 \text { in } 24 \% \\
\text { of patients } \\
(9 / 37)\end{array}$ & $\begin{array}{l}>400 \text { in } \\
94.6 \% \text { of } \\
\text { patients } \\
(35 / 37) \\
\end{array}$ & $\begin{array}{l}>60 \text { in } \\
78.8 \%\end{array}$ & $<60$ in $73 \%$ & - & 16.2 & - & - & - & - & 73 & $\begin{array}{c}87.9(29 / 33 \\
\text { males) }\end{array}$ \\
\hline
\end{tabular}




\begin{tabular}{|c|c|c|c|c|c|c|c|c|c|c|c|c|c|}
\hline $\begin{array}{l}\text { Bauchet et al, } \\
2001(n=19)^{a}\end{array}$ & 89.5 & $\begin{array}{c}190 \\
{[40-600]} \\
\end{array}$ & $\begin{array}{c}460[350- \\
800] \\
\end{array}$ & $\begin{array}{c}90 \\
{[0-500]}\end{array}$ & $\begin{array}{c}25 \\
{[0-90]}\end{array}$ & 100 & 10.5 & 100 & - & 15.8 & 0 & 42.1 & $\begin{array}{c}0 \\
\text { (0/6 males) } \\
\end{array}$ \\
\hline $\begin{array}{l}\text { Creasey et al, } \\
2001(n=21)^{a}\end{array}$ & 78 & 256,9 & $>401$ & 159.6 & 85.7 & 82.6 & $\begin{array}{c}64.8 \\
(11 / 17)\end{array}$ & $100 \%$ & $78.3 \%$ & 34.8 & 8.7 & $\begin{array}{l}61 \text { (systematic } \\
\text { use) }\end{array}$ & - \\
\hline $\begin{array}{c}\text { Sauerwein et al, } \\
2003 \text { (n=427) }\end{array}$ & 98 & - & - & - & - & - & - & $\begin{array}{c}6.4 \text { per } \\
\text { year }\end{array}$ & 1.2 per year & - & - & 95 & - \\
\hline $\begin{array}{l}\text { Vastenholt et al, } \\
2003(n=37)\end{array}$ & 87 & - & - & - & - & - & $\begin{array}{l}43 \text { (daytime) } \\
30 \% \text { (night) }\end{array}$ & $98 \%$ & $59 \%$ & - & - & $\begin{array}{l}60 \text { - clear } \\
\text { benefit in } \\
\text { stool } \\
\text { evacuation }\end{array}$ & $\begin{array}{c}62.5 \\
(20 / 32 \\
\text { males })\end{array}$ \\
\hline $\begin{array}{l}\text { Hamel et al, } \\
2004(n=4)\end{array}$ & 100 & - & $\begin{array}{c}>400 \text { in all } \\
\text { patients }\end{array}$ & - & $\begin{array}{l}<50 \text { in all } \\
\text { patients }\end{array}$ & - & 25 & - & - & - & - & 50 & $\begin{array}{l}75 \text { but not } \\
\text { used } \\
\text { (3/4 males) }\end{array}$ \\
\hline $\begin{array}{l}\text { Kutzenberger et } \\
\text { al, } 2005(n=464)\end{array}$ & 90.5 & 173 & 470 & - & - & - & 17 & $\begin{array}{c}6.3 \text { per } \\
\text { year }\end{array}$ & 1.2 per year & 40.3 & 0.4 & 86.4 & - \\
\hline $\begin{array}{l}\text { Kutzenberger, } \\
2007(n=440) \\
\end{array}$ & 95.4 & 173 & 476 & - & - & - & 17 & $6.3 /$ year & $1.2 /$ year & - & 0.4 & 91 & - \\
\hline $\begin{array}{l}\text { Krasmik et al, } \\
2014(\mathrm{n}=137)\end{array}$ & 78.1 & $\begin{array}{c}272 \\
\text { (sd: } 143)\end{array}$ & $\begin{array}{l}475 \text { (sd: } \\
83 \text { ) }\end{array}$ & - & 96 (sd: 177) & 60.9 & 38.3 & $\begin{array}{c}88.3 \% \\
6.2 \text { per } \\
\text { year } \\
\text { (sd: } 4.5)\end{array}$ & $\begin{array}{c}51.1 \% \\
2.5 \text { per year } \\
\text { (sd: } 2.6)\end{array}$ & 61.3 & 2.2 & - & - \\
\hline $\begin{array}{l}\text { Castano-Boreto et } \\
\text { al, } 2016(n=104)\end{array}$ & 91 & - & $\begin{array}{c}362 \\
(s d: 108)\end{array}$ & - & $<50$ & 100 & 14.4 & $91 \%$ & $15 \%$ & 66.3 & 5.8 & 88 & $\begin{array}{c}64.2 \\
(61 / 95 \\
\text { males) }\end{array}$ \\
\hline $\begin{array}{c}\text { Rasmussen et al, } \\
2015 \text { and Zaer et } \\
\text { al, 2018 } \\
(n=333 / 287)\end{array}$ & 86.2 & - & - & - & - & 86 & 52 & - & - & - & - & 73 & - \\
\hline $\begin{array}{l}\text { Ramos et al, } 2020 \\
\qquad(\mathrm{n}=16)\end{array}$ & 87.5 & - & - & - & $\begin{array}{l}<50 \text { in all } \\
\text { patients }\end{array}$ & - & - & - & $\begin{array}{c}37.5 \\
\text { (SARS users) }\end{array}$ & - & - & 94 & $\begin{array}{c}85 \\
(11 / 13 \\
\text { males })\end{array}$ \\
\hline
\end{tabular}

aNumber of patients that completed the follow-up period (when different from the total number of patients involved in the initial study -> Figures related to bladder functions were then computed based on this number) 
Guiho T, Azevedo-Coste C, Bauchet L, Delleci C, Vignes JR, Guiraud, D, Fattal C. Forty Sacral Anterior Root Stimulation and visceral function outcomes in spinal cord injury - A systematic review of the literature over four decades, World Neurosurgery, 2021.

Supplementary Tab.3 - Implantation procedure and reliability axis (all studies)

\begin{tabular}{|c|c|c|c|c|c|}
\hline Author & $\begin{array}{l}\text { Deafferentation and } \\
\text { Implantation procedure }\end{array}$ & $\begin{array}{l}\text { Complications following } \\
\text { surgery }\end{array}$ & Implant failures & Impact on patients everyday life and long term side effects & Additional information \\
\hline $\begin{array}{l}\text { Robinson et al, } \\
1988(n=22)\end{array}$ & - & Neuropraxia $(n=1)$ & - & $\begin{array}{l}\text { - Patient with pelvic pain awaiting for rhizotomy }(n=1) \\
\text { - Somatic muscle spasms ( } n=1 \text {, preventing implant-driven } \\
\text { micturition) } \\
\text { - Muscle spasms when using SARS implant for erection } \\
\text { ( } n=6 \text {-> Implant never used for sexual purposes) } \\
\text { - Sphincterotomy proposed ( } n=4 \text {-> two refused and did } \\
\text { not use the implant) } \\
\text { - Hydronephrosis pre-implantation ( } n=4) \text { : } \\
\text { * Resolved in two cases } \\
\text { * One patient relapsed } \\
\text { * Grade IV reflux with urgent sphincterotomy in one } \\
\text { patients }\end{array}$ & - \\
\hline $\begin{array}{l}\text { Brindley et al, } \\
1990(n=48)\end{array}$ & - & - & $\begin{array}{l}\text { - } 37.5 \% \text { of patients reported implant failures } \\
-->25 \text { failures in total } \\
\text { - Receiver block failure }(n=7) \\
\text { - New implantation due to cable break }(n=1) \\
\text { - Cable break }(n=5) \\
\text { - Connector failures ( } n=12)\end{array}$ & $\begin{array}{l}\text { - } 17 \% \text { of users noted increased spasms } \\
\text { - Backache }(n=2) \\
\text { - Stimulus pain }(n=1) \\
\text { - Pain leading patient to stop implant use }(n=2) \\
\text { - Increased sweating }(n=6) \\
\text { - Occasional headache }(n=1) \\
\text { - Occasional autonomic dysreflexia }(n=1) \\
\text { - Loss of reflex erections }(n=8) \\
\text { - Increased constipation }(n=4)\end{array}$ & - \\
\hline $\begin{array}{l}\text { MacDonagh et al, } \\
1990(n=12)\end{array}$ & $\begin{array}{l}\text { Intradural implantation in } \\
\text { all cases and } \\
\text { S2-S4 rhizotomy in } 75 \% \text { of } \\
\text { patients }\end{array}$ & $\begin{array}{l}\text { - Suspicion of anterior roots } \\
\text { damage }(n=2) \\
\text { - Cerebrospinal fluid leakage } \\
(n=2)\end{array}$ & - & e & $\begin{array}{l}\text { - No reports of } \\
\text { constipation in any } \\
\text { patients } \\
\text { Benefit: } \\
\text { - Reduced time for bowel } \\
\text { evacuation in any patient }\end{array}$ \\
\hline $\begin{array}{l}\text { Sauerwein et al, } \\
1990(n=12)\end{array}$ & $\begin{array}{l}\text { Initially: } \\
\text {-Intradural implantation } \\
\text { without rhizotomy (16.7\% } \\
\text { of patients) -> Implants } \\
\text { replaced by extradural } \\
\text { devices with extradural } \\
\text { rhizotomy } \\
\text { Finally: } \\
\text {-Extradural implant and } \\
\text { extradural rhizotomy in } \\
\text { all patients }\end{array}$ & $\begin{array}{l}\text { - Cerebrospinal fluid leakage } \\
\text { ( } n=1) \\
\text { - Root damage in all patients } \\
\text { ( } n=12) \\
\text { - Incomplete deafferentation } \\
\text { ( } n=2 \text { and one more is } \\
\text { suspected). }\end{array}$ & - & - & - \\
\hline
\end{tabular}




\begin{tabular}{|c|c|c|c|c|c|}
\hline $\begin{array}{l}\text { Barat et al, } 1993 \\
(n=9)\end{array}$ & $\begin{array}{l}\text { Deafferentation in all } \\
\text { patients but } 3 \text { incomplete } \\
\text { procedure (without S2 or } \\
\text { S4 cutting) }\end{array}$ & - & - & $\begin{array}{l}\text { - Stress incontinence }(n=3) \\
\text { - Reflex incontinence }(n=3) \\
\text { - Mixed incontinence }(n=2) \\
\text { - Second deafferentation needed in } 3 \text { patients (spread to } \\
\text { S1 in two cases) }\end{array}$ & $\begin{array}{l}\text { Benefit: } \\
-3 \text { patients recovered } \\
\text { continence }\end{array}$ \\
\hline $\begin{array}{l}\text { Egon et al, } 1993 \\
(n=30)\end{array}$ & - & $\begin{array}{l}\text { - Major denervation -> } \\
\text { Nearly complete bladder } \\
\text { denervation }(n=2, \text { maximal } \\
\text { recovery after } 1 \text { year) } \\
\text { - Neuropraxia }(n=1) \\
\text {-> Recovery after few } \\
\text { months }(n=1) \\
\text { - Partial denervation }(n=5, \\
\text { with good results few } \\
\text { months post-implantation) }\end{array}$ & - & - Secondary loss of bladder contractions $(n=3)$ & - \\
\hline $\begin{array}{l}\text { Madersbacher et } \\
\text { al, } 1993(n=30)\end{array}$ & $\begin{array}{l}\text { SARS implantation and } \\
\text { deafferentation of roots } \\
\text { for whom anterior } \\
\text { component induced } \\
\text { detrusor contractions - in } \\
\text { first patients - then } \\
\text { extension to all sacral } \\
\text { posterior roots with } \\
\text { better results. } \\
27 \text { intradural implant and } \\
4 \text { extradural implantation }\end{array}$ & $\begin{array}{l}\text { Suspicion of Wallerian } \\
\text { degeneration in one patient } \\
\text { for whom electromicturition } \\
\text { was impossible at the time } \\
\text { of the study }\end{array}$ & - & $\begin{array}{l}\text { - Second deafferentation }(n=5) \text {-> successful procedure for } \\
4 \text { of them }\end{array}$ & $\begin{array}{l}\text { - Severe autonomic } \\
\text { dysreflexia disappeared in } \\
\text { on patient } \\
\text { - Statement claiming that } \\
\text { SARS procedure improved } \\
\text { all patients Quality of life } \\
\text { as well as no patient has } \\
\text { regretted the operation }\end{array}$ \\
\hline $\begin{array}{l}\text { Sarrias et al, } 1993 \\
(\mathrm{n}=7)\end{array}$ & $\begin{array}{l}\text { Extradural implantation } \\
\text { and deafferentation at } \\
\text { the conus medullaris in all } \\
\text { patients }\end{array}$ & $\begin{array}{l}\text { The receiver block was } \\
\text { placed too low in patient } \\
\text { abdominal wall and one of } \\
\text { the device corners broke } \\
\text { through one of the skin } \\
\text { creases }(n=1)->\text { It was } \\
\text { replaced higher up and } \\
\text { cause no further trouble }\end{array}$ & - & - & $\begin{array}{l}\text { Benefit: } \\
\text { - Patient satisfaction } \\
\text { - one patient with upper } \\
\text { urinary tract dilatation } \\
\text { showed improvement } \\
\text { after } 6 \text { months of implant- } \\
\text { driven micturition. }\end{array}$ \\
\hline $\begin{array}{l}\text { Brindley, } 1994 \\
\text { and Brindley, } \\
1995 \text { ( } n=479)\end{array}$ & $\begin{array}{l}\text { - Implantation: } \\
\text { * } 88.2 \% \text { intradural } \\
* 4.6 \% \text { Extradural } \\
* 7.2 \% \text { Unknown } \\
\text { - Rhizotomy: } \\
\text { * } 73.6 \% \text { Rhizotomy } \\
\text { * } 10.4 \% \text { No rhizotomy } \\
* 16 \% \text { Unknown }\end{array}$ & $\begin{array}{l}\text { - Infection following surgery } \\
\text { and device explantation } \\
(\mathrm{n}=3)\end{array}$ & $\begin{array}{l}\text { - Implant failures in } 72 \text { of the } 500 \text { first patients } \\
\text { * } 56 \text { repairs } \\
+21 \text { second failures } \\
\quad 9 \text { replaced } \\
\text { * } 9 \text { replaced by a new stimulator with extradural } \\
\text { electrodes } \\
+2 \text { failures } \\
\text { * } 2 \text { repaired } \\
\text { * Implant needed no repair since implant-driven } \\
\text { micturition remained good }\end{array}$ & $\begin{array}{l}\text { - Infection and explantation during follow-up ( } n=1 \text { ) } \\
\text { - Exposition of the receiver block ( } n=5 \text { ) } \\
\text { - } 95 \text { surgery performed to remedy faults in implant: } \\
* 75 \text { repair procedures (cables, receiver block) }>\text { These } \\
\text { operations were followed by infections in two cases. } \\
* 20 \text { implantations of a new device }->\text { followed by infection } \\
\text { and explantation in one case. } \\
\text { - Death due to renal failure }(n=1) \\
\text { - Deterioration of the upper urinary tract }(n=11) \\
->\text { Including one patient deceased from carcinomatosis, } \\
\text { primary in the bladder } \\
\text { - Second deafferentation ( } n=39 \text { ) } \\
\text { - Spinal roots deterioration during follow up }(n=8)\end{array}$ & - \\
\hline
\end{tabular}




\begin{tabular}{|c|c|c|c|c|c|}
\hline & & & $\begin{array}{l}* 2 \text { waiting to be repaired } \\
- \text { Total number of failures }=98 \\
* 18 \text { receiver failures } \\
* 18 \text { connector failures } \\
* 3 \text { cable fractures } \\
* 42 \text { cables outside their receiver blocks } \\
* 17 \text { Unknown }\end{array}$ & $\begin{array}{l}\text { - Failures of implant driven micturition due to } \\
\text { overstretching of bladder wall }(n=5) \text {-> recovery in all } \\
\text { cases. }\end{array}$ & \\
\hline $\begin{array}{l}\text { Van kerrebroeck } \\
\text { et al, } 1996(n=47)\end{array}$ & $\begin{array}{l}\text { Intradural implantation } \\
\text { and posterior rhizotomy } \\
\text { in all cases }\end{array}$ & $\begin{array}{l}\text { - Cerebrospinal fluid leakage } \\
(n=2) \\
\text { - Wound infection }(n=1) \\
\text { - Nerve damage }(n=2) \\
* 1 \text { permanent } \\
* 1 \text { recovered }\end{array}$ & $\begin{array}{l}\text {-No implant failure (only mention of minor problems } \\
\text { with the external control boxes) }\end{array}$ & $\begin{array}{l}\text { - Spasticity return to preoperative levels } \\
\text { - Second deafferentation }(n=3) \\
\text { - Implant infection }(n=1)->\text { Replacement of the intradural } \\
\text { implant by an extradural one } \\
\text { - AHR induced by stimulation ( } n=2) \\
\text { - Strong lower limbs contraction s during stimulation- } \\
\text { induced erection }(n=12) \\
\text { - Intrathecal baclofen pump }(n=2)\end{array}$ & $\begin{array}{l}\text { Benefits: } \\
\text { - Upper urinary tract } \\
\text { dilatation solved in } 2 \\
\text { patients } \\
\text { - Creatinine clearance } \\
\text { returned to normal values } \\
\text { after implantation }(n=32) \\
\text { - Preoperative } \\
\text { vesicoureteral reflux was } \\
\text { reduced }(n=1) \text { or } \\
\text { disappeared }(n=1) \\
\text { - No interference between } \\
\text { SARS and baclofen pump } \\
\end{array}$ \\
\hline $\begin{array}{l}\text { Van kerrebroeck } \\
\text { et al, } 1997 \text { and } \\
\text { Wielink et al, } \\
1997(n=52)\end{array}$ & $\begin{array}{l}\text { Intradural implantation } \\
\text { and intradural sacral } \\
\text { posterior root rhizotomy } \\
\text { (S2, S3 and S4) }\end{array}$ & $\begin{array}{l}\text { - Difficulties to split anterior } \\
\text { and posterior roots ( } \mathrm{n}=3)-> \\
\text { Persistent reflex post- } \\
\text { operatively needed second } \\
\text { deafferentation } \\
\text { - Persistent neuropraxia } \\
\text { ( } \mathrm{n}=1 \text {, resolved at } 18 \text { months) } \\
\text { - Cerebrospinal fluid leakage } \\
(\mathrm{n}=2)\end{array}$ & $\begin{array}{l}\text { - Minor problems with the external control box are } \\
\text { mentioned } \\
\text { - Cable fracture ( } n=1,18 \text { months after surgery) }\end{array}$ & - & $\begin{array}{l}\text { Benefits: } \\
\text { - Upper urinary tract } \\
\text { dilatation solved in } 2 \\
\text { patients ( } 6 \text { weeks after } \\
\text { rhizotomy) } \\
\text { - Vesicoureteral reflux } \\
\text { observed in } 6 \text { ureters in } 4 \\
\text { patients improved in all } \\
\text { cases }\end{array}$ \\
\hline $\begin{array}{l}\text { Egon et al, } 1998 \\
(n=93)\end{array}$ & $\begin{array}{l}-90.7 \% \text { Intradural } \\
\text { implantation }\end{array}$ & $\begin{array}{l}\text { - Cerebrospinal fluid leakage } \\
\text { ( } n=3 \text { ) } \\
\text { - Nearly complete } \\
\text { denervation ( } n=5 \text {, intradural } \\
\text { implantation, stimulator } \\
\text { could be use after recovery } \\
\text { in } 3 \text { patients) }\end{array}$ & $\begin{array}{l}\text { - Receivers failure }(n=5 \text {, all were replaced) } \\
\text { - Cable failures }(n=4)\end{array}$ & $\begin{array}{l}\text { - Transitory spasticity was mentioned but not } \\
\text { quantitatively documented. In some cases, ablation of S1 } \\
\text { and } \mathrm{L} \text { posterior roots to abolish triceps surae spasticity } \\
\text { - Infection leading to implant removal ( } n=2 \text { ) } \\
\text { - Second deafferentation in } 4.3 \% \text { of patients due to } \\
\text { persistent detrusor reflex activity. } \\
\text { - Deterioration of detrusor responses ( } n=5) \\
\text { - Persistent sphincter dyssynergia ( } n=3, \text { patient refused } \\
\text { sphincterotomy or conus deafferentation) } \\
\text { - Persistent Wallerian degeneration ( } n=1) \\
\text { - Second sphincterotomy ( } n=4 \text {, all continent) } \\
\text { - Renal problems leaded to nephrotomy ( } n=1)\end{array}$ & $\begin{array}{l}\text { Benefit: } \\
\text { - Preoperative } \\
\text { vesicoureteral reflux } \\
\text { disappeared }(n=3)\end{array}$ \\
\hline $\begin{array}{l}\text { Schurch et al, } \\
1998 \\
(n=10)\end{array}$ & $\begin{array}{l}\text { Intradural implantation } \\
\text { and sacral } \\
\text { deafferentation in all } \\
\text { cases }\end{array}$ & $\begin{array}{l}\text { - Surgical incomplete } \\
\text { deafferentation }(n=4)\end{array}$ & & $\begin{array}{l}\text { - AHR persisted and occurred during implant-driven } \\
\text { voiding despite complete sacral deafferentation ( } \mathrm{n}=8 \text { and } \\
\text { unknown condition in } 1 \text { patient) }\end{array}$ & $\begin{array}{l}\text { - DSD resolved in all cases } \\
\text { - No lower limb or trunk } \\
\text { contraction during } \\
\text { stimulation in all patients. }\end{array}$ \\
\hline $\begin{array}{l}\text { Van der Aa et al, } \\
1999\end{array}$ & $\begin{array}{l}\text { Intradural sacral posterior } \\
\text { rhizotomy (S2-S5) and }\end{array}$ & & -Receiver block failure $(n=3)$ & & \\
\hline
\end{tabular}




\begin{tabular}{|c|c|c|c|c|c|}
\hline$(n=37)^{*}$ & $\begin{array}{l}\text { intradural SARS } \\
\text { implantation in all } \\
\text { patients }\end{array}$ & & & & \\
\hline $\begin{array}{l}\text { Bauchet et al } \\
2001(n=19)\end{array}$ & $\begin{array}{l}\text { Intradural implantation } \\
\text { and } S 2 / \mathrm{S} 3 \text { rhizotomy with } \\
\mathrm{S4} / \mathrm{S} 5 \text { roots crushing in all } \\
\text { cases }\end{array}$ & $\begin{array}{l}\text { - Cerebrospinal fluid leak } \\
(\mathrm{n}=2) \\
\text { - Discomfort at the } \\
\text { subcutaneous receptor } \\
\text { (subsequently displaced, } \\
\mathrm{n}=2 \text { ) }\end{array}$ & $\begin{array}{l}\text { - Extradural implantation due to intradural electrode } \\
\text { failure }(n=1) \\
\text { - Replacement of receiver block }(n=1) \\
\text { - Cable disconnection }(n=4) \\
\text { - Charger failure }(n=3)\end{array}$ & $\begin{array}{l}\text { - Bladder fibrosis }(n=1) \\
\text { - Pyelonephritis }(n=1)\end{array}$ & $\begin{array}{l}\text { One woman cannot use } \\
\text { her implant at work } \\
\text { because of inappropriate } \\
\text { toilets }\end{array}$ \\
\hline $\begin{array}{l}\text { Creasey et al, } \\
2001(n=23)\end{array}$ & $\begin{array}{l}\text { Extradural implantation } \\
\text { and intradural rhizotomy } \\
\text { S2-S5 in all cases }\end{array}$ & $\begin{array}{l}\text { - Temporary nerve damage } \\
\text { ( } \mathrm{n}=2 \text {, recovery within } 3 \\
\text { months) }\end{array}$ & - & $\begin{array}{l}\text { - Increased lower limb spasticity ( } n=2) \\
\text { - Incomplete rhizotomy with second deafferentation }(n=1) \\
\text { - Increase in incontinence episodes }(n=4) \\
\text { - Fracture of the second lumbar vertebra } 5 \text { months after } \\
\text { surgery which caused compression of the cauda equina } \\
(n=1)\end{array}$ & $\begin{array}{l}\text { Benefit: } \\
\text { - Reduced time for bowel } \\
\text { evacuation }\end{array}$ \\
\hline $\begin{array}{l}\text { Sauerwein et al, } \\
2003(n=427)\end{array}$ & - & - & - & ( & $\begin{array}{l}\text { - Bladder spasticity } \\
\text { stopped in } 97 \% \text { of all } \\
\text { cases. } \\
\text { - Recovery of kidney } \\
\text { function is mentioned }\end{array}$ \\
\hline $\begin{array}{l}\text { Vastenholt et al, } \\
2003(n=37)\end{array}$ & & $\begin{array}{l}\text { - Cerebrospinal fluid leakage } \\
(n=1) \\
\text { - Neuropraxie }(n=1) \\
\text { - Detrusor weakness }(n=4) \\
\text { Problems solved several } \\
\text { years after surgery }\end{array}$ & $\begin{array}{l}\text {-External equipment (One failure per } 17 \text { and per } 38 \text { user- } \\
\text { years, } n=23 \text { ) } \\
* \text { Cable fracture }(n=16) \\
\text { * Transmitter defects }(n=7) \\
\text { - Internal equipment (One per } 66 \text { user-years, } n=4 \text { in } \\
\text { total). } \\
* 3 \text { receiver replacements }\end{array}$ & $\begin{array}{l}\text { - Strong motor responses to stimulation ( } n=1) \\
\text { - Fibrosis around sacral roots ( } n=2) \\
\text { - Root failures ( } n=1 \text {, but deafferentation enable complete } \\
\text { continence) } \\
\text { - Detrusor weakness }(n=2) \\
\text { - Sphincter weakness }(n=1)\end{array}$ & $\begin{array}{l}\text {-Erection never used for } \\
\text { sexual intercourse }\end{array}$ \\
\hline $\begin{array}{l}\text { Hamel et al, } \\
2004\end{array}$ & $\begin{array}{l}\text { Intradural rhizotomy and } \\
\text { extradural implantation }\end{array}$ & $\begin{array}{l}\text { - Cerebrospinal fluid leakage } \\
\text { spontaneously resolved } \\
(n=1)\end{array}$ & - & - & - \\
\hline $\begin{array}{l}\text { Kutzenberger et } \\
\text { al, } 2005(n=464)\end{array}$ & $\begin{array}{l}\text { Deafferentation } \\
\text { performed in all surgery } \\
\text { with a success rate of } \\
94.1 \%\end{array}$ & $\begin{array}{l}\text { - Cerebrospinal fluid leak } \\
(n=6) \\
- \text { Infection of the implant } \\
(n=5) \\
\text { - Dehiscent wound }(n=2) \\
\text { - Hemorrhages }(n=2, \\
\text { requiring no further } \\
\text { treatment) }\end{array}$ & $\begin{array}{l}\text { - } 70 \text { Implant defects }->34 \text { repair surgery were necessary } \\
* 16 \text { Receiver exchange and cable repair } \\
* 5 \text { Cable repair alone } \\
* 9 \text { Extradural implant }\end{array}$ & $\begin{array}{l}\text { - Second deafferentation ( } \mathrm{n}=8 \text { to interrupt dysreflexia) } \\
\text { - Bladder overdistension and neurogenic failures are } \\
\text { mentioned but not quantitatively documented. }\end{array}$ & - \\
\hline $\begin{array}{l}\text { Kutzenberger et } \\
\text { al, } 2007(n=440)\end{array}$ & $\begin{array}{l}\text { Intradural } \\
\text { deafferentation and } \\
\text { implantation. Rhizotomy } \\
\text { performed in all surgery } \\
\text { with a success rate of } \\
95.2 \%\end{array}$ & $\begin{array}{l}\text { - Cerebrospinal fluid leak } \\
(n=6) \\
\text { - Infection of the implant } \\
\text { ( } n=5) \text { with further } \\
\text { reimplantation in } 4 \text { cases } \\
\text { - Dehiscent wound }(n=2) \\
\text { - Hemorrhages }(n=2, \\
\text { requiring no further } \\
\text { treatment) }\end{array}$ & $\begin{array}{l}-81 \text { Implant defects }->44 \text { repair surgery were necessary } \\
* 26 \text { Receiver exchange and cable repair } \\
* 6 \text { Cable repair alone } \\
* 12 \text { Extradural implant with } 1 \text { further withdrawal due to } \\
\text { an infection }\end{array}$ & $\begin{array}{l}\text { - Second deafferentation ( } n=8 \text { at conus terminlis to } \\
\text { interrupt dysreflexia) } \\
\text { - Bladder overdistension and neurogenic failures are } \\
\text { mentioned but not quantitatively documented. }\end{array}$ & - \\
\hline
\end{tabular}




\begin{tabular}{|c|c|c|c|c|c|}
\hline $\begin{array}{l}\text { Krasmik et al, } \\
2014 \quad(n=137)\end{array}$ & $\begin{array}{l}\text { Intradural implantation } \\
\text { and deafferentation S2 to } \\
\text { S5 in all cases }\end{array}$ & $\begin{array}{l}\text { - Cerebrospinal fluid leakage } \\
(n=8) \\
\text { - Infection }(n=3)\end{array}$ & $\begin{array}{l}\text { - Defect of cables }(n=19) \\
\text { - Defect of stimulation plate }(n=19) \\
\text { - Dislocation of the stimulator plate }(n=16) \\
\text { - Undetermined cause of stimulator failure }(n=15)\end{array}$ & $\begin{array}{l}\text {-Incomplete rhizotomy with second deafferentation at the } \\
\text { conus medullaris }(n=4) \\
\text { - Additional urological interventions in } 43 \text { patients } \\
* 22 \text { Outlet obstruction } \\
\text { * } 10 \text { Vesicoureteral reflux } \\
\text { * } 10 \text { Incontinence } \\
* 9 \text { Urethral strictures } \\
\text { - Problems with condom fixation }(n=3)\end{array}$ & $\begin{array}{l}\text { In } 54 \text { patients, a total of } \\
83 \text { surgical revisions were } \\
\text { performed (17 patients } \\
\text { underwent more than one } \\
\text { revision) }\end{array}$ \\
\hline $\begin{array}{l}\text { Castano-Boreto } \\
\text { et al, 2016 } \\
(\mathrm{n}=104)\end{array}$ & $\begin{array}{l}\text { Extradural implantation } \\
\text { and posterior rhizotomy } \\
\text { of S2-S5 sacral roots in all } \\
\text { cases }\end{array}$ & - & - Failure of the receiver block $(n=1)$ & $\begin{array}{l}\text { - Infections few months after implantation ( } n=2) \\
\text { - Cable extrusion }(n=2) \\
\text { - Extrusion of the receiver block }(n=2)\end{array}$ & - \\
\hline $\begin{array}{l}\text { Ramos et al, } 2020 \\
(n=16)\end{array}$ & $\begin{array}{l}\text { SARS implantation and } \\
\text { deafferentation } \mathrm{S} 2 \text { to } \mathrm{S} 4 \\
\text { in all cases }\end{array}$ & $\begin{array}{l}\text { Neuropraxia with } \\
\text { spontaneous resolution } \\
\text { after } 12 \text { months }(n=2)\end{array}$ & $\begin{array}{l}\text { - Malfunction/damage of the external hardware mostly } \\
\text { due to operator misuse }(n=10)\end{array}$ & - Extrusion of the receiver block $(n=2)$ & $\begin{array}{l}\text { - } 85 \% \text { of patient obtained } \\
\text { stimulation-induced } \\
\text { erections but only } 2 \text { use } \\
\text { SARS ( } 6 \text { patients sexually } \\
\text { active before SARS } \\
\text { procedure }-4 \text { using a } \\
\text { penile prosthesis) }\end{array}$ \\
\hline
\end{tabular}

: Not Documented. 
Guiho T, Azevedo-Coste C, Bauchet L, Delleci C, Vignes JR, Guiraud, D, Fattal C. Forty Sacral Anterior Root Stimulation and visceral function outcomes in spinal cord injury - A systematic review of the literature over four decades, World Neurosurgery, 2021.

\section{Supplementary Tab.4 - Multicentric studies}

\section{$\underline{\text { Study and patients characteristics }}$}

\begin{tabular}{|c|c|c|c|c|c|c|c|c|}
\hline Authors & $\begin{array}{c}\text { Number of } \\
\text { patients / \% of } \\
\text { male patient }\end{array}$ & Mean age in years $\left({ }^{*}\right)$ & $\begin{array}{l}\text { Lesion profile } \\
\text { T-Tetraplegia } \\
\text { P-Paraplegia } \\
\end{array}$ & $\begin{array}{c}\text { \% of complete } \\
\text { SCl }\end{array}$ & $\begin{array}{c}\text { Mean age of the lesion at } \\
\text { the time of implantation } \\
\text { (in years) }\end{array}$ & $\begin{array}{l}\text { Patients follow up after } \\
\text { implantation } \\
\text { (in years) }\end{array}$ & Study type & $\begin{array}{l}\text { Level of } \\
\text { evidence }\end{array}$ \\
\hline Sauerwein et al, 1990 & $12 / 50$ & $\begin{array}{c}36 \\
{[24-52]^{a}}\end{array}$ & $\begin{array}{l}\text { Trauma: } 12 \\
\mathrm{~T}-1 / \mathrm{P}-11\end{array}$ & 83.3 & $\begin{array}{c}9 \\
{[1-27]} \\
\end{array}$ & $\begin{array}{c}1.31 \\
{[2.5-0.08]} \\
\end{array}$ & RS & IV \\
\hline Brindley et al, 1990 & $50 / 76$ & $\begin{array}{c}32.08 \\
{[57-19]^{\mathrm{a}}}\end{array}$ & $\begin{array}{c}\text { Trauma: } 48 \\
T-10 / \mathrm{P}-38 \\
\text { MS: } 2\end{array}$ & 77.08 & - & $\stackrel{-}{[5-11]}$ & RS & IV \\
\hline $\begin{array}{c}\text { Brindley, } 1994 \text { and } \\
\text { Brindley, } 1995\end{array}$ & $500 / 54.2$ & - & $\begin{array}{c}\text { Trauma: } 378 \\
T-122 / \mathrm{P}-256 \\
\text { Unspecified : } 98 \\
\end{array}$ & 85.5 & - & $\begin{array}{c}4.07 \\
{[0.25-16.1]}\end{array}$ & RS & III \\
\hline
\end{tabular}

\section{Benefits on visceral functions}

\begin{tabular}{|c|c|c|c|c|c|c|c|c|c|c|c|c|c|}
\hline \multirow{2}{*}{ Author } & \multirow{2}{*}{$\begin{array}{l}\text { Use of SARS for } \\
\text { micturition (\%) }\end{array}$} & \multicolumn{2}{|c|}{$\begin{array}{l}\text { Bladder volume } \\
\text { (ml) }\end{array}$} & \multicolumn{2}{|c|}{$\begin{array}{l}\text { Residual urine } \\
\text { (ml) }\end{array}$} & \multicolumn{2}{|c|}{ Incontinent episodes } & \multicolumn{2}{|c|}{ Urinary tract infections } & \multicolumn{2}{|c|}{ Autonomic dysreflexia (\%) } & \multirow{2}{*}{$\begin{array}{c}\text { Use for } \\
\text { defecation (\%) }\end{array}$} & \multirow{2}{*}{$\begin{array}{c}\text { Use for erection } \\
(\%)\end{array}$} \\
\hline & & Before & After & Before & After & Before & After & Before & After & Before & After & & \\
\hline $\begin{array}{l}\text { Sauerwein et al, } 1990 \\
\qquad(n=12)\end{array}$ & 75 & - & 565 & - & $\begin{array}{l}<50 \text { in } \\
75 \% \text { of } \\
\text { patients }\end{array}$ & 75 & 25 & - & - & - & - & - & - \\
\hline $\begin{array}{c}\text { Brindley et al, } 1990 \\
(n=48)^{\mathrm{a}}\end{array}$ & 85.4 & - & - & - & - & - & $\begin{array}{c}44 \\
\text { (SARS users) }\end{array}$ & - & $\begin{array}{c}29.2 \% \\
\text { (SARS users) }\end{array}$ & - & - & 56.2 & $\begin{array}{c}43.2 \\
(16 / 37 \text { males })\end{array}$ \\
\hline $\begin{array}{c}\text { Brindley, } 1994 \text { and } \\
\text { Brindley, } 1995(n=479)^{a}\end{array}$ & 86.2 & - & - & - & - & - & - & - & - & - & - & - & - \\
\hline
\end{tabular}

\section{Implantation procedure and reliability axis}

\begin{tabular}{|c|c|c|c|c|c|}
\hline Author & $\begin{array}{l}\text { Deafferentation and } \\
\text { Implantation procedure }\end{array}$ & $\begin{array}{l}\text { Complications } \\
\text { following surgery }\end{array}$ & Implant failures & Impact on patients everyday life and long term side effects & $\begin{array}{l}\text { Additional } \\
\text { information }\end{array}$ \\
\hline $\begin{array}{l}\text { Sauerwein et } \\
\text { al, } 1990 \text { ( } n=12)\end{array}$ & $\begin{array}{l}\text { Initially: } \\
\text {-Intradural implantation } \\
\text { without rhizotomy } \\
\text { (16.7\% of patients) -> }\end{array}$ & $\begin{array}{l}\text { - Cerebrospinal } \\
\text { fluid leakage } \\
(n=1)\end{array}$ & - & - & - \\
\hline
\end{tabular}




\begin{tabular}{|c|c|c|c|c|c|}
\hline & $\begin{array}{l}\text { Implants replaced by } \\
\text { extradural devices with } \\
\text { extradural rhizotomy } \\
\text { Finally: } \\
\text {-Extradural implant and } \\
\text { extradural rhizotomy in } \\
\text { all patients }\end{array}$ & $\begin{array}{l}\text { - Root damage in } \\
\text { all patients } \\
\text { ( } n=12) \\
\text { - Incomplete } \\
\text { deafferentation } \\
\text { ( } n=2 \text { and one } \\
\text { more is } \\
\text { suspected). }\end{array}$ & & & \\
\hline $\begin{array}{l}\text { Brindley et al, } \\
1990(\mathrm{n}=48)\end{array}$ & - & - & $\begin{array}{l}-37.5 \% \text { of patients reported implant failures } \\
-->25 \text { failures in total } \\
\text { - Receiver block failure }(n=7) \\
\text { - New implantation due to cable break ( } n=1) \\
\text { - Cable break }(n=5) \\
\text { - Connector failures ( } n=12 \text { ) }\end{array}$ & $\begin{array}{l}\text { - } 17 \% \text { of users noted increased spasms } \\
\text { - Backache }(n=2) \\
\text { - Stimulus pain }(n=1) \text { and pain leading to stop implant use }(n=2) \\
\text { - Increased sweating }(n=6) \\
\text { - Occasional headache }(n=1) \\
\text { - Occasional autonomic dysreflexia }(n=1) \\
\text { - Loss of reflex erections }(n=8) \text { and Increased constipation }(n=4)\end{array}$ & - \\
\hline $\begin{array}{l}\text { Brindley, } 1994 \\
\text { and Brindley, } \\
1995(n=479)\end{array}$ & $\begin{array}{l}\text { - Implantation: } \\
* 88.2 \% \text { intradural } \\
* 4.6 \% \text { Extradural } \\
* 7.2 \% \text { Unknown } \\
\text { - Rhizotomy: } \\
* 73.6 \% \text { Rhizotomy } \\
* 10.4 \% \text { No rhizotomy } \\
* 16 \% \text { Unknown }\end{array}$ & $\begin{array}{l}\text { - Infection } \\
\text { following surgery } \\
\text { and device } \\
\text { explantation } \\
(n=3)\end{array}$ & $\begin{array}{l}\text { - Implant failures in } 72 \text { of the } 500 \text { first patients } \\
* 56 \text { repairs }>21 \text { second failures } \\
\quad 9 \text { replaced and } 12 \text { repaired }->3 \text { third failures } \\
* 9 \text { replaced by a new stimulator with extradural electrodes }->2 \text { failures } \\
2 \quad 2 \text { repaired } \\
* 5 \text { Implant needed no repair since implant-driven micturition remained good } \\
* 2 \text { waiting to be repaired } \\
\text { - Total number of failures }=98 \\
* 18 \text { receiver failures } * 18 \text { connector failures } * 3 \text { cable fractures } \\
* 42 \text { cables outside their receiver blocks } * 17 \text { Unknown }\end{array}$ & $\begin{array}{l}\text { - Infection and explantation during follow-up ( } n=1) \\
\text { - Exposition of the receiver block }(n=5) \\
\text { - } 95 \text { surgery performed to remedy faults in implant: } \\
\text { * } 75 \text { repair procedures (cables, receiver block) }>2 \text { infections } \\
\text { * } 20 \text { implantations of a new device }>1 \text { infection and explantation } \\
\text { - Death due to renal failure }(n=1) \\
\text { - Deterioration of the upper urinary tract }(n=11) \\
\text { - Including one death from carcinomatosis, primary in the bladder } \\
\text { - Second deafferentation ( } n=39 \text { ) } \\
\text { - Spinal roots deterioration during follow up ( } n=8) \\
\text { - Failures of implant driven micturition due to overstretching of } \\
\text { bladder wall }(n=5) \text { - recovery in all cases. }\end{array}$ & \\
\hline
\end{tabular}

